\title{
Gastos com educação no período de 1994 a 1999*
}

Ivan Castro deAImeida

Palavras-chave: custos da educação; indicadores

educacionais; custo-aluno: financiamento daeducação.
* A produção eo tratamento das informações degasto comeducação foramfeitoscomacolabo ração deMariaAlicedaCunha Fernandes, Margareth Pessoae MaruskaPereiradeAImeida.

\section{Resumo}

Os indi cadores de gasto com educação apresentam al guns desafi os que são a obtenção do total consolidado das três esferas de governo, a el aboração de uma série histórica ea possi bilidade de poder comparar os resultados com outros países. O trabal ho apresenta resultados de uma série histórica de gasto públ ico com educação desde 1994 a 1999, por nível de ensino e por dependência admi nistrativa, produzidos de modo a tratar os dados definanciamento e gasto público com educação a partir de uma metodologia desenvolvida pel o Instituto de Pesquisas Econômicas A plicadas (I pea) para a produção do gasto social brasileiro, para fazer frente àqueles desafios. A seguir, são apresentados os principais indicadores comparados entre regi ões brasileiras eentre países da América do Sul ecom países-membros da Organização para Cooperação e Desenvol vimento Econômico (OCDE). Com isso, pretende-se mostrar um caminho possível para o tratamento de informações relativas a financiamento e gasto públ ico com educação utilizando-se dos bal anços gerais de Estados e municípios e do Sistema Integrado de Admi nistração Financei ra (Siafi) do governo federal.

\section{Introdução}

A formulação de políticas adequadas naárea da educação pública por aqueles que tomam as decisões de implementá-las depende, em parte, do conhecimento do gasto realizado, seu tamanho, medido como porcentual do PIB, e as prioridades estabelecidas, podendo ser medidas por meio do gasto por aluno, pois é esse valor quemostra o investimento unitário empreendido pelo governo em cada nível de ensino. A análise histórica para o período 1994 a 1999 aponta para um aumento considerável do gasto com educação no ensino fundamental, principalmente na esfera municipal, com a criação do Fundo de Manutenção e Desenvolvimento do Ensino Fundamental e da Val orização do Magisté rio (Fundef), por meio da lei implementada em 1998, eque teve como objetivo garantir recursos para o ensino fundamental, euma melhora na redistribuição dos recursos al ocados para a educação em cada uni dade da Federação (UF) de forma mais eqüitativa (correspondendo, na prática, a 15\% das receitas líquidas dos Estados e municípios). A inovação desse fundo foi estabel ecer um critério institucional paraa sua partilha, proporcionalmente ao número de alunos de cada uma das redes estaduais emunicipais, dentro de cada UF (Brasil, 2003). A pesar de esse fundo ser apenas de natureza contábil, elefavoreceo aumento dos gastos municipais com educaçãotanto emtermos absolutos como unitariamente Outra políticaimportantepara se anal isar o gasto com educação éa da fixação por meio do governo federal de um teto mínimo, definido anualmente, para o gasto por al uno. Caso esse val or não seja atingido por al guma esfera de governo, faz-se a complementação, que, ao final, compensa por disparidades na distribuição dos recursos. 
Entreo período 1997 e1999, o gasto real izado nas redes municipais aumentou, em termos nominais, $45 \%$, e, em termos reais (ajustados pelo IPCA anual), 31\%. Em contrapartida, nas redes estaduais houve um crescimento nominal de $17 \%, 5 \%$ em termos reais, no mesmo período. Ressaltese que essas políticas, por terem caráter redistributivo, não al teram deforma significativa o total do gasto com educação em relação ao PIB, nunca acima de $4,3 \%$ do PIB, exclusive, pagamentos de inativos e pensionistas.

Com estetrabal ho, pretende-semostrar as principais mudanças ocorridas no Brasil na segunda metade da década de 90 , anal isando os seus resultados por região e UF. Além disso, apresentar-se-á um conjunto de tabelas que possibilitam a sua comparatividade ao longo do tempo, no período de 1994 a 1999, e que contribuem na discussão acerca do padrão de gasto realizado pelo governo, incluindo as três esferas de governo, no sistema educacional público brasileiro.

\section{Os levantamentos de gastos com educação}

Dados referentes ao financiamento da educação pel os Estados epela União eram levantados por técnicos do antigo Serviço de Estatística deEducação e Cul tura (Seec) - atual Coordenação-Geral de Estatísticas Especiais, do Instituto Nacional de Estudos e Pesquisas Educacionais Anísio Teixeira (Inep/MEC) - , a partir dos balanços publicados no Diário Oficial. A coleta de dados sobre os recursos gastos pelos municípios no financiamento da educação vinha sendo efetuada pel o Instituto Brasileiro de Geografia e Estatística (IBGE), até 1991. A partir dessa data, o IBGE passou essa atividade para o MEC. Tentou-se efetuar a coleta por meio de mala direta, porém o retorno não chegou a $50 \%$.

Em janeiro de 1995, o Seec preparou um caderno intitulado Educação no Brasil apresentando um compacto de dados. Os últimos dados sobreal unos e docentes datavam de 1993, entretanto os dados sobreo financiamento da educação eram de 19881990, inclusive dados orçamentários do próprio Ministério da Educação (MEC), como a distribuição de recursos à educação. O último estudo do MEC sobre custo médio por aluno/ano era de 1988 (publicado em 1988, com dados de 1986). A fal ta de dados atual izados envolvendo o financiamento da educação il ustra o fato de quenão havia interesse, anteriormente, por partedo MEC em dados sobre despesas e custos da educação.

A partir de1997, ol nep buscou estabelecer parcerias com o I pea ecom o IBGE do Ministério de Planejamento, Orçamento e Gestão (MOG), para a produção de informações que permitissem o cál culo de indicadores para fins de orientar formadores de política educacional epermitir comparações com indicadores internacionais, recebendo ajuda técnica efinancei ra da OCDE eapoio do Banco Mundial para esse projeto. Dessa parceria, foi produzida a série histórica de 1994-1999, com a partici pação do Instituto deEstudos de Políticas Econômicas eSociais (lepes), que produziu uma série histórica de gasto público social para esse período (Fernandes, 2001).

A base de dados utilizada para o levantamento das despesas do governo federal é o próprio sistema delançamentos contábeis e acompanhamento financeiro (Siafi) e de el aboração eacompanhamento da execução orçamentária (Sidor), por apresentar registros em nível desagregado por projetos eatividades de governo, permitindo que suas informações sejam reagrupadas adequadamente e eliminadas despesas cuja classificação não se conformam com a definição metodológica das ações de educação (gastos com hospitais universitários é um exemplo típico). Essa metodologiafoi primeiramente trabal hada pelo grupo da Disoc/l pea, com o intuito de estimar o gasto público social (Abrahão; Fernandes, 1999).

Para os governos estaduais, as informações provieram do Departamento de Contas Nacionais (Decna) do IBGE, quefaz a coleta diretamentenos bal anços anal íticos anuais de todos os Estados da Federação. O mesmo Decna/IBGE fornece os dados de uma amostra composta pel os municípi os das capitai s e de outros pertencentes a dez regi ões metropolitanas, num total de 186 (177 em 1994, e 186 de 1996 em diante) governos locais, os quais congregam mais de $40 \%$ da população do País. No período 1994-1996, a esses municípios foram acrescentados 93 outros, constantes de pesqui sa direta efetuada pel o I pea, por intermédio de sua Diretoria de Estudos Sociais (Disoc), em dez Estados. A partir dessa amostra, faz-se a expansão dos gastos com educação para o universo dos municípios brasileiros. 
As informações das contas de governos estaduai s emunici pais não chegam ao nível de detal hamento do governo federal e, embora se consiga identificar as despesas por níveis de ensino, deve-se aceitar como correta a cl assi ficação feita nos registros contábeis daquel as esferas de governo, sabendo-se, porém, que a classificação da despesa por funções e programas não é se guida ou interpretada demaneira uni forme por Estados e municípios. Examinando as contas dos Estados para esse período, nota se que al guns deles começam a registrar, dentro de subprogramas genéricos deadministração, despesas específicas de manutenção ou expansão do ensino fundamental e médio. Emboratais registrosnão modifiquem os resultados totais da área, podem levar a distorções na análise das despesas por nível de ensino. Para o ano de 1999, os dados de gastos municipais foram estimados a partir da base Finbra da STN e, com as informações das receitas dos municípios para o ano de1999, em seguida, inferir o montantedestinado à educação, combinando-secom ototal de gasto na função educação disponível na base. A distribuição dos gastos seguiu o padrão de gasto dos municípios para o ano de 1998.

A expansão dos dados da amostra de municípi os foi feita pel o método deregressão linear, obedecendo, em linhas gerais, aos seguintes critérios (Fernandes, 2001):

- Os municípios das capitais, por teremuma estrutura degastos diferenciada dos demais, não entram no cálculo do coeficiente (gastos em rel ação ao número de alunos matriculados na redemunici pal); entretanto, todos os demais municípios pesquisados, por UF, são, a princípio, estudados, eliminando-se, em etapa posterior, aquel es considerados outliers, para que o coeficiente reflita, da mel hor maneira possível, o comportamento de despesas do conjunto dos municípios restantes;

- Para cadaEstado da Federação (exceto nas Regiões Norte e Centro-Oeste, onde a maior parte dos municípios estudados é constituída pelas capitais das unidades da Federação, ou outros de grande ou médio porte), foi construído um "espel ho" das despesas efetuadas, constituído pela soma dos municípios diretamente pesquisados, exceto aquel es considerados outliers, que reflete a forma como os municípios distribuem os seus gastos na área de educação, entre despesas com pessoal, outras despesas correntes, investimentos e outras despesas de capital; ; e

- Os coeficientes cal culados para cada Estado são multiplicados pel o total de matrículas na rede própria de ensino dos municípios restantes, e a despesa distribuída deacordo com o comportamento observado no seu respectivo "espel ho".

Para efeito da consolidação dos gastos dos três níveis de governo, foram considerados dois critérios:

- De origem dos recursos, no qual se identifica a esfera degoverno que financia o dispêndio, o que significa incluir as transferências voluntárias de recursos para os outros níveis governamentais na esfera onde se originou o gasto; e

- De responsabilidade pel o gasto, que registra todas as despesas executadas por esfera, seja com recursos oriundos da própria esfera de governo, seja com numerário transferido por outros níveis governamentais.

Uma vez queas bases utilizadas para os gastos da União, Estados e municípios englobam dados da administração di reta e indireta, foram eliminadas as transferências intragovernamentais, que traduzem o fluxo de recursos entre a administração central e seus órgãos autárquicos, para anular a dupla contagem de dispêndios ou de ingressos.

Na área de atuação social, Educação e Cultura é dividida em subgrupos que serelacionam com os principais programas de educação e/ou níveis deensino, como constam dos registros da contabilidade pública, baseado na classificação funcionalprogramática definida pela Lei no 4.320/64 (MachadoJúnior, Reis, 1991):

... educação de crianças de 0 a 6 anos, ensino fundamental, ensino médio, educação superior, educação física e desporto, ensino supl etivo e educação de jovens e adultos; educação especial, assistência a educandos, patrimônio artístico e difusão cultural, manutenção de atividades administrativas.

Partindo do estudo feito pelo I pea/Disoc, os gastos com educação efetuados pel o setor público foram compilados de modo compatível às metodologias adotadas pel os organismos internacionais como o Instituto deEsta tísticas da Unesco (UIS/Unesco) e a OCDE, quedifere daadotada por aqueleórgão, principalmente, nos seguintes aspectos: 
- A área de educação não inclui gastos com cultura ou com educação física e desporto, quefazem parte do levantamento da Disoc/lpea para a área de atuação social; e

- Para comparabilidade internacional com educação, são contabilizadas parcel as não remuneratórias pagas a pessoal ("nãosalário", auxílios transporte eal imentação, entre outros benefícios a servidores, denominados pel a metodologia internacional de fringe benefits), enquanto pela metodologia Disoc/l pea estes gastos são considerados em uma área social própria, intitulada Benefícios a Servidores. ${ }^{1}$

Para adaptar as informações aos conceitos da OCDE e do Bird, foram promovidas as seguintes apropriações das contas governamentais:

- Os subgrupos Ensino Fundamental, Ensino Médio, Ensino Supletivo, Educação Especial e Manutenção de Atividades Admi nistrativas foram fundidos num único título denominado Ensino Fundamental e Médio, nas três esferas de governo;

- No subgrupo Assistência a Educandos do governo federal, foram identificadas as despesas referentes à "educação fundamental e média" e "educação superior". Nos governos estaduais, foram essas despesas rateadas proporcional mente entre "ensino fundamental e médio" e "educação superior"; nas contas dos governos munici pais, os dispêndi os foram totalmenteagregados ao "ensino fundamental e médio"; e

- Do título "educação superior" constam todas as ações governamentais de manutenção de cursos de graduação e pós-graduação, inclusive pesquisas sob responsabilidade das instituições de ensino superior; contém, também, o rateio do subgrupo Assistência a Educandos, nos governos estaduais, mas exclui gasto com hospitai s universitários, que devem ser considerados como gasto com saúde.

Além desses procedimentos, foi necessário al ocar em cada um dos três novos grupos resultantes as despesas com fringe benefits ou "não-sal ário" pagos a pessoal da área de educação. Para o que foram obedecidos os seguintes critérios:

- No governo federal recorreu-seà pesquisa di reta na base de dados, levantandose todos os benefícios pagos a servidores do Ministério da Educação, por UF; e
- Nas contas estaduais e municipais, foram cotejados os totais de despesas de pessoal com as do pessoal da área de educação, construindo-se um coeficiente da participação deste sobre aquele; em seguida, os coeficientes foram aplicados aos valores totais de pagamentos de salário-família e deobrigações patronais feitos por cada uma daquelas esferas governamentais.

Esse critério justifica-se tendo em vista que, para a educação básica, o sistema, tanto de pagamento de pessoal como de atendimento ao al uno éintegrado, isto é, servea todos os níveis deensino da educação bási$\mathrm{ca}$, independentemente da modal idadee do nível considerado. Este procedimento éadotado pela mai oria dos países para a al ocação dessas despesas, pois, como no Brasil, a separação dessas despesas não é possível diretamente dos dados de contas públicas. Segundo Milla (1998), ao tratar da experiência da partici pação da Espanha no proje to deindicadores da OCDE, que anual mente é resumido no anuário Education at a glance (OECD, 2002), existem al gumas dificuldades para distribuir certos tipos de gastos, como, por exemplo, o depagamento de pessoal e da educação, benefícios a servidores e, isto é feito por meio de estimativas, de uma porcentagem do total que, em princípio, a administração pública deve destinar a esses benefícios. Essas dificuldades já tinham sido apontadas anteriormente por Barro, ao realizar um estudo sobre as informações de financiamento egastos com educação no âmbito dos países-membros da OCDE (Barro, 1998). Por isso, a OCDE passou a concentrar esforços no sentido de mel horar a qual idade da informação e conseqüentemente a sua comparabilidade. A estratégia adotada para superar essas dificuldades pela OCDE foi o lançamento do projeto Indicators of Education Systems (Ines), com o objetivo não somente de obter dados de educação para a produção de indicadores educacionais comparáveis entre os países-membros, mas também, deauxiliar os partici pantes do projeto a desenvolver as capaci dades necessárias para a produção da informação. O resultado dessa ini ciativa culminou com a primeira publicação Education at a glance, em 1991 (Barro, 1998).

A regi onal ização das despesas do governo federal éfeita para permitir a consol idação

\footnotetext{
1 Paraas definiçõesmetodológicas, ver'WEI SpecificDataCollection Manual",May 2003. Unesco-UIS OECDPublication.
} 
no âmbito subnacional ea produção dos indicadores por UF, seguindo o conceito de real ização da despesa, reflete mel hor os recursos alocados em cada um dos sistemas educacionais, e, portanto, possi bilitando o cál culo do indicador gasto por al uno.

A categorização dos dados definanciamento e gastos públicos com educação seguem as normas e preceitos constitucionais, tendo como fonte básica a Lei Federal no 4.320/64 e as diversas atual izações ao Iongo dos anos. Os conceitos utilizados na apropriação de gastos sociais são a seguir explicitados, para facilitar a análise dos dados, e evitar interpretações ou comparações equivocadas:

- aquantificação dos dados segueo conceito de origem dos recursos, isto é, estão computadas todas as despesas diretas necessárias à prestação dos serviços (pessoal exceto encargos sociais, outros custeios, be nefíci os pagos a pessoas ou uni dades familiares, investimentos e outras despesas de capital), bem como as transferências de re cursos a outras esferas de governo e a entidades privadas emultigovernamentais;

- foram agregadas, sob o título Nacional, aquelas despesas para as quais não se pôde encontrar uma destinação por UF ou mesmo por grande região, bem como as feitas por transferências de numerário para o exterior; sob a rubrica da correspondente região, quando a regi onal ização do gasto era possível , mas não a sua "estadual ização";

- as despesas com pessoal referem-se exclusivamente à remuneração de pessoal ativo, isto é, vencimentos evantagens fixas e despesas variáveis, pessoal temporário, pagamentos de sentenças judiciárias, despesas de exercícios anteriores e indenizações e restituições referentes a pagamentos de pessoal ativo; e

- dispêndios com salário-família, obrigações patronais, outros benefícios eauxílios de natureza previdenciária ou assistencial pagos a servidores, bem como encargos com auxílio-creche, auxílio-refeição ou alimentação, auxílio-transporte ou val e-transporte, contribuição para o Pasep, foram considerados em separado, numaárea de atuação social específica, intitulada Benefícios a Servidores Públicos.

A organização do sistema educacional brasileiro é descentralizada com os Estados e municípios, sendo os principais responsáveis pela oferta e gerenciamento da educação básica, enquanto o governo federal é responsável pela organização da educação superior e, além de oferecer e gerenciar, majoritariamente, o sistema educacional público.

Dessa maneira, a organização das escolas por "grupos" de níveis de ensino reflete na forma de apropriação do gasto público em educação. Como conseqüência, as despesas tendem a ser contabilizadas a partir da sua natureza, e identificadas, a seguir, pelo programa e subprogramas correspondentes. Se a uma dada despesa corresponder, simultaneamente, a mais de um programa ou subprograma educacional, não refleti rá total mente o gasto da sua categoria. Exemplificando, a despesa com o pagamento de um docenterefere-sea seu salário mais benefícios - quando examinada a sua natureza - , mas pode ser identificada como um gasto em qual quer nível de ensino a que este docente esteja vinculado (podendo ser vinculado a mais de um nível de ensino). Do ponto de vista contábil, podem ocorrer duas formas de apropriação desse tipo de despesa: o gasto com o docente pode ser apropriado em al gum nível a que o docenteesteja vinculado; ou em programa genérico deadministração do sistema, caso ele atue em mais de um nível de ensino.

Para superar essetipo de dificuldadee apresentar os dados de forma a que os indicadores educacionais reflitam o mais coerentemente possível a realidade educacional, o Inep tem adotado uma estratégia de distribuir os gastos da educação básica, para cada ti po de sistema educacional (estadual e municipal), de acordo com pesos definidos a partir do tamanho do sistema (combinação dos respectivos pesos nos níveis de ensino, do número de docentes, número de turmas etotal deal unos matriculados). Seguindo essa metodologia, col oca-seem uma única conta o gasto com pessoal, sem qualquer associação com o tipo de programa, excetuando-seos deensi no do terceiro grau. A partir desse total, redistribui-se o gasto pelos diversos níveis de ensino da educação básica (educação infantil, ensino fundamental - inclusive educação de jovens e adultos) e ensino médio (inclusive educação de jovens e adultos).

A partir do ano de 1997, o l pea deixou de fazer a consolidação das três esferas de governo, passando a cuidar apenas das informações do governo federal, distribuindoas por Estado da Federação nos anos de 1997 
e 1998. Por essa razão, assumiu o Inep/MEC a responsabilidade de alocar por Estados as despesas da União no ano de 1999 e de consol i dar os gastos das três esferas de governo para o período em referência.

As fontes de informação são as mesmas queas do período anterior (1994-1996) e a alocação das despesas de Estados e municípios foi tratada por processo de crítica dos dados levantados pelo IBGE/ Decna, que permitiu uma mel hor al ocação de gastos pelos diferentes níveis de educação (infantil, fundamental, superior, etc.). A expansão da amostra para o universo dos municípios brasilei ros seguiu a mesma metodol ogia expl i citada anteriormente, apenas com a ampliação da amostra de municípios.

Os gastos com educação formam agregados pela sua finalidade e não pela sua apropriaçãosetorial paraser compatível com a metodologia internacional adotada pela Unesco e OCDE. Dados, muitas vezes considerados pela contabilidade pública como setoriais da educação, são excluídos desse trabal ho. Essetrabal ho foi iniciado em 1995 pela equipe do Departamento de Política Social do Ipea. O critério adotado para a apropriação do gasto em que se consideram os gastos diretos de cada esfera de governo foi independente da fonte de financiamento. Nos gastos diretos não são incluídos aqueles correspondentes a pagamentos de inativos epensionistas. As apropriações dos gastos federais e estaduais são censitárias, enquanto os gastos munici pais foram estimados por meio de uma amostra representativa por UF de 248 municípios, segundo o seu perfil socioeconômico edemográfico e sua estrutura de gasto social. Nelas são incluídas obrigatoriamentetodas as despesas real izadas pelas capitais dos Estadose pelas metrópoles locais, val ores esses correspondentes a mais de $50 \%$ do total dos gastos munici pais. Além disso, somente as transferências líqui das intergovernamentais são incluídas no processo de apropriação, mas quando calculadas pela real ização da despesa, e, portanto, pela ótica do gasto, são excluídas do total, para evitar a dupla contagem. Por isso, na metodologia internacional, decidiu-se não incluir gastos com o aparelho do Estado que dá suporte à educação e com os gastos com hospitais universitários, exceto aquel es correspondentes aos gastos educacionais.

Há, também, dados que, tradicionalmente, não são apropriados como gasto com educação. Neles incluem-se os gastos com obrigações patronais e benefíci os aos servidores, aqui excluídos os gastos com inativos e pensionistas, que possuem rubrica própria. Além desses, incluem-se os gastos com bolsas de estudo, merenda escolar e gastos com pesquisas que estão adjuntos aos programas acadêmi cos das universidades.

Ressalte-seque os enfoques internacionais partem da lógica de aval iar os gastos e não os custos, apesar de que tratado demaneira adequada, pode-seinferir acerca do seu custo. Assim, internacionalmente, o quese busca avaliar é o total de gasto no sistema educacional. Os gastos por nível de ensino para a educação básica são estimados, tendo em vista queas esferas de governo apropriamo gasto em uma única rubrica de programa educacional , não levando em conta a infra-estrutura, eos docentes quelecionam em mais de um nível de ensino. Assim, os gastos por nível de ensino são val ores estatísticos e não-contábeis, pois el es são agregados no seu total por natureza do seu gasto e redistribuído pelos níveis de ensino, proporcional mente ao tamanho de cada sistema educacional (quanto ao número de docentes, quanto ao número de turmas e quanto ao número deal unos). A razão, para isso, équea contabilização dos balanços dos governos não éfeita pro rata.

\section{Avaliação dos gastos com educação no período 1994-1999}

O gasto, como porcentagem do PIB, apresenta dois patamares para o período: abai xo de 4\% até 1997 e, em 1998 e 1999, em torno de $4,2 \%$ do PIB. Este nível de gasto parece refletir o total da destinação legal para o setor educacional (Abrahão, Sadeck, 2002).

Municípios, em queo setor público federal ainda é responsável por uma parcela significativa das despesas nos Estados e/ou recebem verbas do governo federal para programas específicos (e.g. Fundescola), tendem a refletir um porcentual de gasto com educação em relação ao PIB mais al to do que o esperado, já que esse gasto não se refleteno PIB estadual. Isto ocorrenos Estados do AC, $A P, T O, M A, P I, R N, P B, A L$ e SE.

Nota-se que, para as Regiões Norte e Nordeste, o crescimento do gasto em rel ação ao PIB é mais significativo que nas Regiões Sul eSudeste, nesse período. 
Tabela 1 - Variação percentual do gasto com educação em relação ao PIB

\begin{tabular}{|c|c|c|c|}
\hline Região & 1994 & 1999 & $\operatorname{Var}(\%)$ \\
\hline Brasil & 3,8 & 4,3 & 14,4 \\
\hline Norte & 4,5 & 6,8 & 51,9 \\
\hline Nordeste & 5,2 & 7,4 & 41,3 \\
\hline Sudeste & 3,2 & 3,4 & 7,6 \\
\hline Sul & 3,5 & 3,6 & 4,9 \\
\hline Centro-Oeste & 4,3 & 5,5 & 27,9 \\
\hline
\end{tabular}

Fonte: Disoc/Ipea, Decna/IBGE, Inep/MEC.

Semel hante resultado obtém-se para o gasto por al uno. Mas, como veremos adiante, como referencial internacional, o gasto por al uno é muito abaixo da maioria dos países, apesar deo gasto como porcentual do PIB estar nos níveis dos demais países em desenvolvimento (Tabela 16).

Tabela 2 - Variação percentual do gasto por aluno do ensino fundamental - Preços correntes

\begin{tabular}{|c|c|c|c|}
\hline Região & 1994 & 1999 & Var (\%) \\
\hline Brasil & 295 & 691 & 134,2 \\
\hline Norte & 192 & 569 & 196,4 \\
\hline Nordeste & 164 & 507 & 209,1 \\
\hline Sudeste & 362 & 826 & 128,2 \\
\hline Sul & 359 & 802 & 123,4 \\
\hline Centro-Oeste & 266 & 839 & 215,4 \\
\hline
\end{tabular}

Fonte: Disoc/Ipea, Decna/IBGE, Inep/MEC.

Comparando, em termos reais, isto é, anual, calculado pelo IBGE, tem-seumcresem preços de 1999, ajustados pelo IPCA cimento bem mais modesto.

Tabela 3 - Variação percentual do gasto por aluno do ensino fundamental - Preços de 1999

\begin{tabular}{|c|c|c|c|}
\hline Região & 1994 & 1999 & $\operatorname{Var}(\%)$ \\
\hline Brasil & 459 & 691 & 50,5 \\
\hline Norte & 299 & 569 & 90,5 \\
\hline Nordeste & 255 & 507 & 98,7 \\
\hline Sudeste & 563 & 826 & 46,6 \\
\hline Sul & 559 & 802 & 43,6 \\
\hline Centro-Oeste & 414 & 839 & 102,7 \\
\hline
\end{tabular}

Fonte: Disoc/lpea, Decna/IBGE, Inep/MEC

Nota: Usaram-se os índices anuais do IPCA para ajustar a preços de 1999.

Dados publicados pelo IBGE (variação de $55,6 \%$ - 94/99).

Analisando esses indicadores ecomparando os anos de 1998 e 1999, tem-se um quadro bastante diferente, pois os dados mostramumaestabilização do gasto com educação, isto é, a sua tendência ao não-crescimento real (Tabel a 4). 
Tabela 4 - Variação percentual do gasto com educação em relação ao PIB

\begin{tabular}{|c|c|c|c|}
\hline Região & 1998 & 1999 & Var (\%) \\
\hline Brasil & 4,2 & 4,3 & 1,4 \\
\hline Norte & 6,8 & 6,8 & - \\
\hline Nordeste & 7,1 & 7,4 & 4,2 \\
\hline Sudeste & 3,4 & 3,4 & 0,6 \\
\hline Sul & 3,5 & 3,6 & 3,1 \\
\hline Centro-Oeste & 5,1 & 5,5 & 7,0 \\
\hline
\end{tabular}

Fonte: Disoc//pea, Decna/IBGE, Inep/MEC.

Isto pode ser visto mel hor por meio do gasto por aluno no ensino fundamental, em que o crescimento em valores correntes (Tabela 5) em nível nacional é de 3,4\%reais, há um decréscimo no gasto por aluno para o ensino fundamental de acordo com os dados apresentados na Tabela 6.

Tabela 5 - Variação percentual do gasto por aluno do ensino fundamental - Preços correntes

\begin{tabular}{|c|c|c|c|}
\hline Região & 1998 & 1999 & $\operatorname{Var}(\%)$ \\
\hline Brasil & 668 & 691 & 3,4 \\
\hline Norte & 564 & 569 & 0,9 \\
\hline Nordeste & 465 & 507 & 9,0 \\
\hline Sudeste & 800 & 826 & 3,3 \\
\hline Sul & 750 & 802 & 6,9 \\
\hline Centro-Oeste & 839 & 839 & - \\
\hline
\end{tabular}

Fonte: Disoc/lpea, Decna/IBGE, Inep/MEC.

Tabela 6 - Variação percentual do gasto por aluno do ensino fundamental - Preços de 1999

\begin{tabular}{|c|c|c|c|}
\hline Região & 1998 & 1999 & $\operatorname{Var}(\%)$ \\
\hline Brasil & 675 & 691 & 2,3 \\
\hline Norte & 570 & 569 & $-0,2$ \\
\hline Nordeste & 470 & 507 & 7,9 \\
\hline Sudeste & 809 & 826 & 2,1 \\
\hline Sul & 758 & 802 & 5,8 \\
\hline Centro-Oeste & 848 & 839 & $-1,1$ \\
\hline
\end{tabular}

Fonte: Disoc/lpea, Decna/IBGE, Inep/MEC.

Nota: Usaram-se os índices anuais do IPCA para ajustar a preços de 1999

Dados publicados pelo IBGE (variação de 1,089\% - 98/99).

O gasto público no ensino fundamental tem aumentado substantivamente nas redes públicas municipaise dimi nuído nas redes estaduais (Tabel as 7 e 8). 
Tabela 7 - Variação percentual do gasto estadual com educação (Em R\$ Mil de 1999)

\begin{tabular}{|c|c|c|c|}
\hline Região & 1998 & 1999 & $\operatorname{Var}(\%)$ \\
\hline Brasil & 18.619 .131 & $18.456 .238,0$ & $-0,9$ \\
\hline Norte & 1.421 .480 & $1.373 .006,0$ & $-3,4$ \\
\hline Nordeste & 3.275 .306 & $3.371 .162,0$ & 2,9 \\
\hline Sudeste & 9.234 .942 & $9.198 .073,0$ & $-0,4$ \\
\hline Sul & 2.829 .279 & $2.768 .848,0$ & $-2,1$ \\
\hline Centro-Oeste & 1.858 .124 & $1.745 .149,0$ & $-6,1$ \\
\hline
\end{tabular}

Fonte: Disoc/lpea, Decna/IBGE, Inep/MEC.

Nota: Usaram-se os índices anuais do IPCA para ajustar a preços de 1999.

Dados publicados pelo IBGE (variação de 1,089\% - 98/99).

Tabela 8 - Variação percentual do gasto municipal com educação (Em R\$ Mil de 1999)

\begin{tabular}{|c|c|c|c|}
\hline Região & 1998 & 1999 & $\operatorname{Var}(\%)$ \\
\hline Brasil & $18.418 .480,0$ & $16.108 .374,0$ & $-12,5$ \\
\hline Norte & $1.406 .161,0$ & $1.109 .551,0$ & $-21,1$ \\
\hline Nordeste & $3.240 .009,0$ & $4.304 .371,0$ & 32,9 \\
\hline Sudeste & $9.135 .421,0$ & $6.843 .118,0$ & $-25,1$ \\
\hline Sul & $2.798 .789,0$ & $1.870 .240,0$ & $-33,2$ \\
\hline Centro-Oeste & $1.838 .100,0$ & $650.641,0$ & $-64,6$ \\
\hline
\end{tabular}

Fonte: Disoc/lpea, Decna/IBGE, Inep/MEC.

Nota: Usaram-se os índices anuais do IPCA para ajustar a preços de 1999.

Dados publicados pelo IBGE (variação de 1,089\% - 98/99).

Pode-se al egar que isso foi conseqüência da municipalização do ensino, o que é parcial mente verdade, mas, mesmo assim, quando se compara o gasto por aluno entre as redes deensino vê-seque, o sistema estadual é mai or nas Regiões Norte e Nordeste do queas municipais, mas muito pouco acima, esignificativamentemenor nas Regi ões Sudeste e Sul. Nacional mente, o gasto por aluno das redes munici pais foi $15 \%$ (Tabela 9) maior que o gasto por aluno das redes estaduais.

Tabela 9 - Gasto por aluno no ensino fundamental - 1999

\begin{tabular}{|c|c|c|c|}
\hline Região & Estadual & Municipal & $\operatorname{Var}(\%)$ \\
\hline Brasil & 622 & 718 & 15,4 \\
\hline Norte & 553 & 548 & $-0,9$ \\
\hline Nordeste & 520 & 464 & $-10,7$ \\
\hline Sudeste & 663 & 1.044 & 57,5 \\
\hline Sul & 635 & 986 & 55,3 \\
\hline Centro-Oeste & 759 & 835 & 9,9 \\
\hline
\end{tabular}

Fonte: Disoc/lpea, Decna/IBGE, Inep/MEC.

Observa-sequeisto foi uma tendência de 1998a1999, comomostramastabelas, medidas em preços correnteseem preços de 1999 (Tabelas 10 e11), ajustados pelo IPCA anual. 
Tabela 10 - Gasto por aluno no ensino fundamental (inclui todas as modalidades de ensino) - Em R\$ correntes

\begin{tabular}{|l|c|c|c|c|}
\hline \multirow{2}{*}{ Região } & \multicolumn{2}{c|}{1999} & \multicolumn{2}{c|}{1998} \\
\cline { 2 - 5 } & Estadual & Municipal & Estadual & Municipal \\
\hline Brasil & 622 & 718 & 629 & 663 \\
\hline Norte & 553 & 548 & 572 & 528 \\
\hline Nordeste & 520 & 464 & 501 & 416 \\
\hline Sudeste & 663 & 1.044 & 662 & 1.034 \\
\hline Sul & 635 & 986 & 665 & 836 \\
\hline Centro-Oeste & 759 & 835 & 817 & 676 \\
\hline
\end{tabular}

Fonte: Disoc/Ipea, Decna/IBGE, Inep/MEC.

\section{Tabela 11 - Gasto por aluno no ensino fundamental (inclui todas as modalidades} de ensino) - Em R \$ de 1999

\begin{tabular}{|l|c|c|c|c|}
\hline \multirow{2}{*}{ Região } & \multicolumn{2}{c|}{1999} & \multicolumn{2}{c|}{1998} \\
\cline { 2 - 5 } & Estadual & Municipal & Estadual & Municipal \\
\hline Brasil & 622 & 718 & 634 & 731 \\
\hline Norte & 553 & 548 & 564 & 558 \\
\hline Nordeste & 520 & 464 & 530 & 473 \\
\hline Sudeste & 663 & 1.044 & 676 & 1.064 \\
\hline Sul & 635 & 986 & 647 & 1.004 \\
\hline Centro-Oeste & 759 & 835 & 774 & 851 \\
\hline
\end{tabular}

Fonte: Disoc/lpea, Decna/IBGE, Inep/MEC

IPCA Anual - Dados publicados pelo IBGE (variação de 1,089\% - 98/99).

A matrícula no ensino médio tem, nos últimos anos, crescido muito mais que no ensino fundamental. No período 1997-1999, enquanto o crescimento da matrícula nas redes estaduais e municipais do ensino fundamental regular foi de $7,3 \%$, nas mesmas redes e período, a matrícula do ensino médio regular cresce $28,3 \%$, como se pode ver na Tabela12.

Com o gasto por al uno não acompanhando esse crescimento de matrícula (Tabela 13).

Tabela 12 - Matrícula nas redes estaduais e municipais - 1997-1999

\begin{tabular}{|l|c|c|}
\hline \multicolumn{1}{|c|}{ Região } & Fundamental & Médio \\
\hline 1999 & 32.753 .824 & 6.423 .162 \\
\hline 1997 & 30.535 .072 & 5.006 .714 \\
\hline $\operatorname{Var} 97-99(\%)$ & 7,3 & 28,3 \\
\hline
\end{tabular}

Fonte: MEC/Inep

Tabela 13 - Variação percentual do gasto por aluno do ensino médio - Preços correntes

\begin{tabular}{|c|c|c|c|}
\hline Região & 1997 & 1999 & $\operatorname{Var}(\%)$ \\
\hline Brasil & 670 & 643 & $(4,0)$ \\
\hline Norte & 550 & 543 & $(1,3)$ \\
\hline Nordeste & 552 & 529 & $(4,2)$ \\
\hline Sudeste & 726 & 679 & $(6,5)$ \\
\hline Sul & 630 & 622 & $(1,3)$ \\
\hline Centro-Oeste & 798 & 811 & 1,6 \\
\hline
\end{tabular}

Fonte: Disoc/lpea, Decna/IBGE, Inep/MEC. 
Na educação superior, o gasto por al uno é determinado por uma combinação de três fatores essenciais: tipo de instituição, pesquisa e esfera de governo. Desta maneira, o gasto por al uno, passa a ter três padrões distintos.

O mais alto, acima de $R \$ 10 \mathrm{mil}$, como nos casos de SP, RS, RJ e DF, em que a educação superior é quase que exclusi vamente, oferecida em grandes universi dades, em que o gasto com pesquisa é um fator rel evante, para a determi nação do total do gasto.

Há al gumas exceções, como o caso do RN, em que o gasto por al uno para os anos de 1997-1998 é aproximadamente R\$ 14 mil. Isto se deve ao fato de que, neste período, o gasto com sentenças trabalhistas, após decisões judiciais na UFRN, leva a um superdi mensionamento desse gasto.

0 gasto por aluno intermediário, entre $R \$ 5$ mil e $R \$ 10$ mil por al uno, é, normalmente, conseqüência de uma combinação de gasto com universi dades federais e estaduais, e com al gumas faculdades munici pais isoladas. Estes são os casos, por exemplo, de RO, AM, PA, $M A, C E, P B, P E, S E, B A, M G, E S, P R$ e MT.
O gasto por al uno abaixo de $\mathrm{R} \$ 5 \mathrm{mil}$. Pode ser de natureza distinta. Nos Estados do Norte, mais precisamente, nos casos de RR, AP e TO, apesar de serem exclusivamente gastos de universi dade federal, provavel mente, quasenão possuem gastos com pesquisa e com um limitado programa de pós-graduação. Goiás (R\$4.400 por aluno em 1997-1998 e R 5.200 em 1999) possui uma rede de facul dades isol adas estaduais e municipais, representando cerca de $20 \%$ do total da matrícula. Santa Catarina (R\$ 2.500 por aluno em 1998 e R\$ 4.400 em 1999), em particular, tem uma redemunicipal e estadual, mas principal mente municipal, de universidades efacul dades isoladas - 29.656 alunos matriculados de um total de 50.106 alunos degraduação das instituições públicas para o ano de 1999 - representando mais de $50 \%$ do total da matrícula da educação superior do setor público no Estado. Como esses programas são intensivos em programas de graduação, os gastos por al uno tendem a ser baixos.

Independentemente dessas características, vê-se que no período mais recente, o gasto corrente por al uno do setor público nesse nível de ensino tem-se estabilizado e, em termos reais, tende à queda (Tabel as 14 e 15).

Tabela 14 - Variação percentual do gasto por aluno do superior - Preços correntes

\begin{tabular}{|c|c|c|c|}
\hline Região & 1998 & 1999 & $\operatorname{Var}(\%)$ \\
\hline Brasil & 9.789 & 9.756 & $-0,3$ \\
\hline Norte & 6.039 & 6.404 & 6,0 \\
\hline Nordeste & 7.549 & 6.661 & $-11,8$ \\
\hline Sudeste & 12.874 & 12.295 & $-4,5$ \\
\hline Sul & 6.216 & 7.804 & 25,5 \\
\hline Centro-Oeste & 8.654 & 9.193 & 6,2 \\
\hline
\end{tabular}

Fonte: Disoc/Ipea, Decna/IBGE, Inep/MEC.

Tabela 15 - Variação percentual do gasto por aluno do ensino superior - Preços de 1999

\begin{tabular}{|c|c|c|c|}
\hline Região & 1998 & 1999 & $\operatorname{Var}(\%)$ \\
\hline Brasil & 9.896 & 9.756 & $-1,4$ \\
\hline Norte & 6.105 & 6.404 & 4,9 \\
\hline Nordeste & 7.631 & 6.661 & $-12,7$ \\
\hline Sudeste & 13.014 & 12.295 & $-5,5$ \\
\hline Sul & 6.284 & 7.804 & 24,2 \\
\hline Centro-Oeste & 8.748 & 9.193 & 5,1 \\
\hline
\end{tabular}

Fonte: Disoc/lpea, Decna/IBGE, Inep/MEC.

Nota: Usaram-se os índices anuais do IPCA para ajustar a preços de 1999.

Dados publicados pelo IBGE (variação de 1,089\% - 98/99). 


\section{A comparação internacional}

Desde 1973 a OCDE tem desenvolvido com seus membros esforços em produzir indicadores comparáveis, mas essa iniciativa não resultou em dados concretos (Bottani, Tuijnman, 1994). Essas iniciativas foram retomadas em 1987, culminando com a publicação da primei ra edição da Education at a glance em 1991 (Barro, 1998). Esta publicação tem sido atualizada anualmente, com mel horias tanto na cobertura dos dados como na qualidade das informações (Almeida, 2001). Para o ano de 1999, tem-se o seguinte resultado comparativo (Tabela 16) entre diversos países (OECD, 2002):

Tabela 16 - Gasto público com educação - 1998-1999

\begin{tabular}{|l|c|c|c|}
\hline \multicolumn{2}{|c|}{ Gasto público 1998/1999 } & \multicolumn{3}{c|}{ Gasto/Aluno } \\
\hline \multicolumn{1}{|c|}{ Ajustado para R\$ pela PPP } & (\%) PIB & Fundamental & Superior \\
\hline Austrália & 5,0 & 4.178 & 10.084 \\
\hline Japão & 3,5 & 4.506 & 8.839 \\
\hline México & 4,4 & 943 & 4.119 \\
\hline Coréia do Sul & 4,1 & 2.441 & 4.606 \\
\hline Portugal & 5,7 & 2.991 & 4.130 \\
\hline Estados Unidos & 5,2 & 5.661 & 16.529 \\
\hline Média OCDE & 5,2 & 3.637 & 9.823 \\
\hline Argentina & 4,5 & 1.401 & 4.821 \\
\hline Brasil & 4,3 & 691 & 9.756 \\
\hline Chile & 4,2 & 1.463 & 5.493 \\
\hline Paraguai & 4,8 & 754 & 4.700 \\
\hline
\end{tabular}

Fonte: Education at a glance 2002, OECD.

Os dados mostram que, com exceção do Japão, os gastos públicos nos países desenvolvidos estão na faixa de $5 \%$ a $6 \%$ do PIB, enquanto nos países em desenvolvimento esse patamar está na fai xa de $4 \%$ a $5 \%$ do PIB. Ressalte-se que, apesar de os esforços de todos os setores públicos serem compatíveis com os seus níveis de desenvolvimento, quando se analisam os resultados nos níveis de ensino, a disparidade é muito grande. Isso é refletido na diversi dade do gasto por aluno. Para os outros países, foi considerado "ensino fundamental " os seis anos da educação básica, deacordo com a metodologia internacional - ISCED 97 (OECD,1997), denominado de primary education. Ressal te-seque o Japão apresenta um gasto total relativamentebaixo, mas mantém a qual idadecom um gasto por al uno, nessenível deensino, acima da média da OCDE. No caso brasileiro, ocorre o contrário. Brasil, Coréia do Sul, Argentina e Chile apresentam gastos totais semel hantes, o mesmo não se pode dizer quando se avalia o gasto por aluno para esse nível de ensino. No caso brasileiro, menor que todos eles.
Quanto ao nível superior, o gasto brasi leiro segue a média da OCDE, apesar de os outros países apresentarem como nível superior os programas terciários tanto universitários com não-universitários (ou de curta duração). Este último tende a ter um gasto por al uno muito menor devido à natureza do programa. Por exemplo, na Austrália, o gasto por aluno em programas terciários universitários foi de 7.998 dólares, PP, ou ajustado ao real para R\$ 6.879. Enquanto os programas terciários universitários apresentaram um gasto por al uno de 12.588 dólares, em reais, $\mathrm{R} \$ 10.825$. No Chile, a rel ação gasto por aluno nos programas universitários edo gasto por al uno nos programas não-universitários (ou de curta duração) foi de 2,16 (R \$ 6.580 para universitário e, R\$3.049 para não-universitário).

\section{Comentários finais}

Os dados acima demonstram que, por umlado, houveum grandeesforço no Brasil degarantir um gasto por educação compatível com o seu nível de desenvolvimento, e 
deredistribui ção mais eqüitativa dos recursos medida pelo gasto com educação como porcentual do PIB (7,33\% na Região Norte e, 3,39\% na Região Sudeste), mas, por outro lado, apresenta um resul tado individual, isto é, por al uno, muito aquém do quese espera para um ensino de qual idade, como se pode ver na Tabela 16. Os números tambémevidenciam quenessa reorganização da distribuição dos recursos, há uma tendênciaà municipal ização do sistema, enquanto queos Estados têm progressivamentediminuído a sua partici pação relativa no gasto com a educação básica, principalmente, no ensino fundamental. Essa redução reflete-se não somente no total dos gastos (o queseria natural acontecer, devido ao processo de municipalização do ensino fundamental), mas também no gasto por al uno.

Tal vez o mai or desafio seja o de encontrar mecanismos que, mesmo com a capacidade limitada de expansão do gasto com educação, possam el evar o gasto por al uno na educação básica, e produzir a mel horia da qualidade do aprendizado que, afinal, é o que qual quer governo deveal mejar como resultado da oferta dos serviços públicos educacionais para a população.

\section{Referências bibliográficas}

ABRAHÃO, J.; FERNANDES, M. A. Sistema de Informações sobre os Gastos Públicos da Área de Educação - SIGPE: Diagnóstico para 1995. Brasília: Ipea, 1999. (Texto para Discussão, n. 674).

ABRAHÃO, J.; SADECK, F. Capacidade de financiamento público ao gasto em educação no Brasil - estimativa para as três esferas de governo para o ano 2000. Brasília: I pea, 2002. (Texto para Discussão em preparação).

ALMEIDA, I. C. A comparação internacional de indicadores definanciamento egasto com educação. Em Aberto, v. 18, n. 74, dez. 2001.

BARRO, S. The prospects for developing internationally comparable education finance statistics for Latin American Countries: A Preliminar Assessment. The World Bank, Sept. 1998. (LCSHD Paper Series).

BOTTANI N.; TUIJNMAN, A. International Education Indicators: framework, development and Interpretation. In: MAKING Education Count: devel oping and using international indicators. OECD Publications, Sept. 1994.

BOTTANI, N. Os indicadores educacionais da OCDE: propósitos, limites e processos de produção. In: SEMINÁRIO INTERNACIONAL DE AVALIAÇÃO EDUCACIONAL. Anais... Brasília: Inep, 1998.

BRASIL. Ministério da Educação. Fundef - Relatório Sintético 1998 - 2002. Brasília: MEC, 2003. Disponível em: www.mec.gov.br

FERNANDES, M. Alice. Gasto público social, 1994 a 1998 - consolidação das três esferas de governo. Publicação lepes. Disponível em: www.iespesbsb.gov.br Acessado em agosto de 2001.

MACHADO JÚNIOR, J. T.; REIS, H. C. A Lei 4.320 Comentada. 24. ed. IBAM, 1991.

MILLA, J. I. Sistema de indicadores de la OCDE y cuestionários UOE aplicación de los indicadores de la OCDE: caso España. In: INDICADORES Educativos Comparados en el Mercosur. Chile: Unesco/Preal/Mineduc, Ago. 1998.

OECD. Classifying educational programmes: manual for ISCED - 97 Implementation in OECD Countries. OECD Publications, Nov. 1997.

OECD. Education at a glance: 2002 OECD Indicators. OECD Publications, 2002. 
Ivan Castro de AImei da é especial ista em políticas públicas e gestão governamental do governo federal e professor da Associação de Ensino Unificado do Distrito Federal (AEUDF), tendo partici pado da el aboração do projeto e dos indicadores educacionais do Mercosul Educacional e das reuniões técnicas dos projetos da Unesco/ OCDE, Secab e Cúpula das A méricas desde 1997.

ivan@inep.gov.br

\section{Abstract}

Providing a consistent time series of finance education indicators for all three levels of government - Federal, State and Local - and making it internationally comparable represents a great challenge, due to the need of dealing with the information in a way that makes it possible to provide a collection of data for the whole government. This work presents a time series from 1994 to 1999 for all three levels of government based on a methodology originally developed by the Institute for Research of Applied Economics (Ipea) to generate indicators on Social Expenditure, in order to face those challenges. Afterwards, it presents most of the results compared among Brazilian regions and with South America as well as with OECD Countries. The goal is to present an alternative in dealing with the finance data in Brazil based on State and Local Balance Sheet Accounts and based on the Integrated Finance Management System for the Federal Government (Siafi).

Keywords: education; expenditure on education; education indicators; expenditure on public education per student; education finance. 


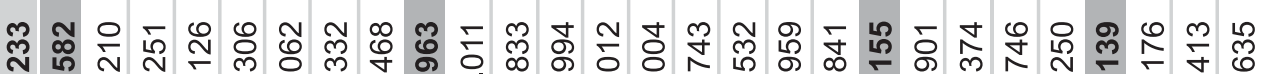
F

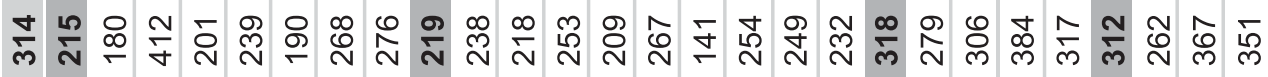

$\frac{0}{\frac{8}{\circ}}$

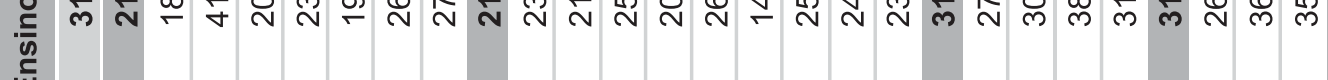
-

$\frac{8}{\frac{2}{20}}$

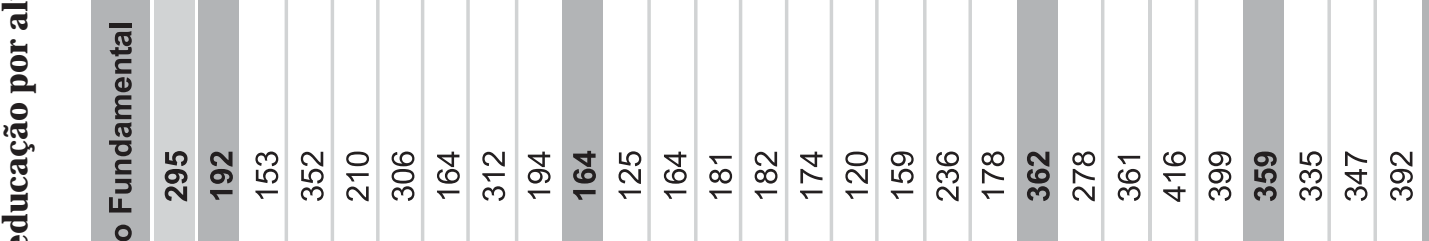

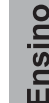
焉

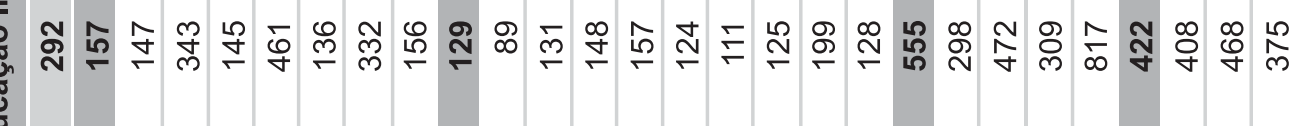

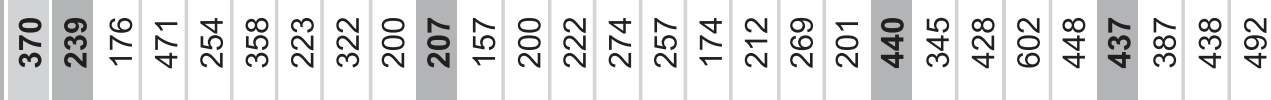

$\frac{8}{4}$

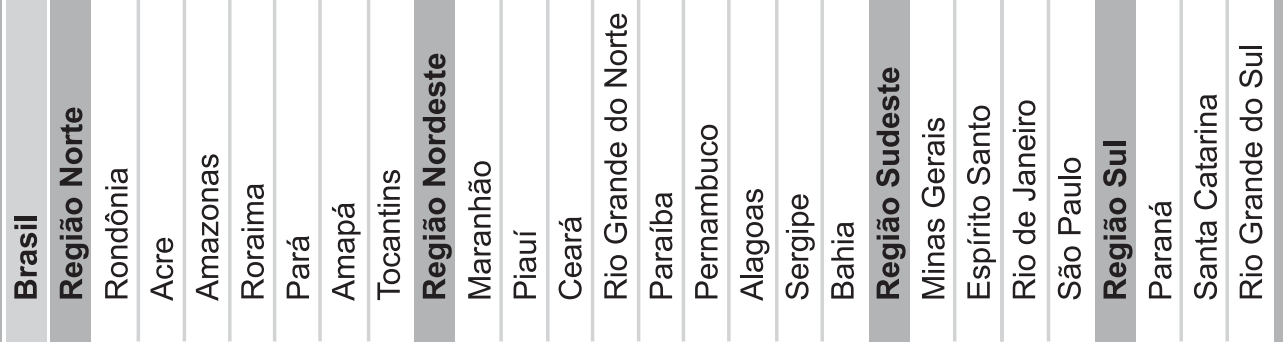




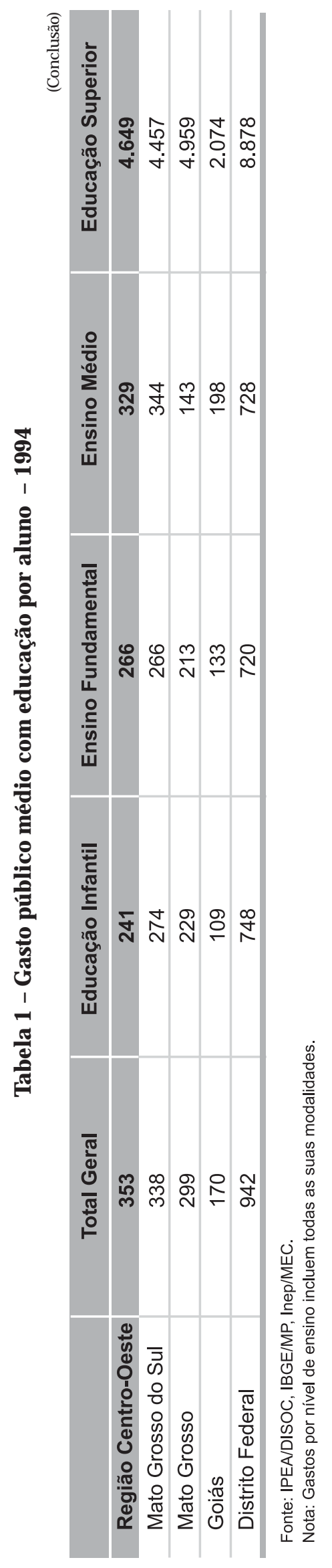




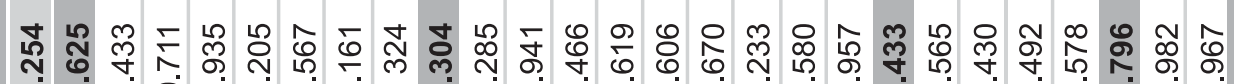

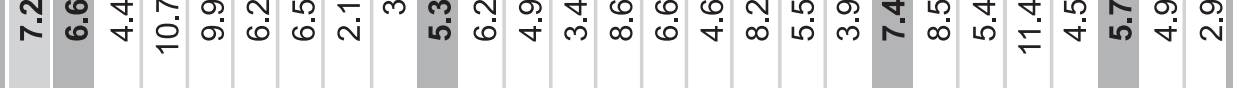

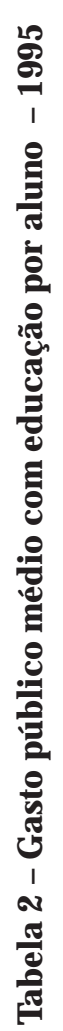

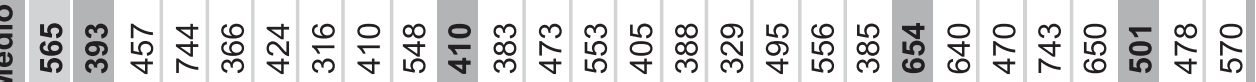

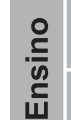

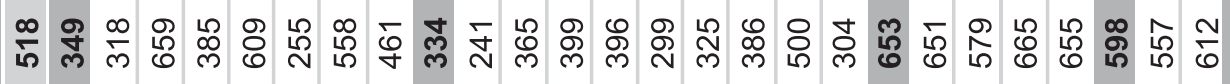
突

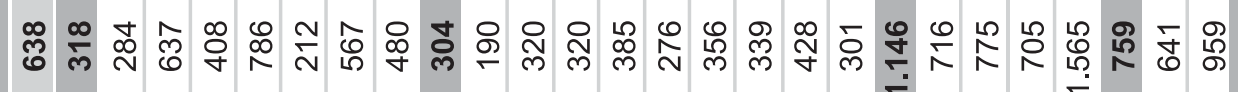

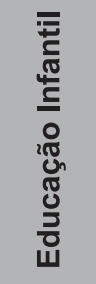

ङ

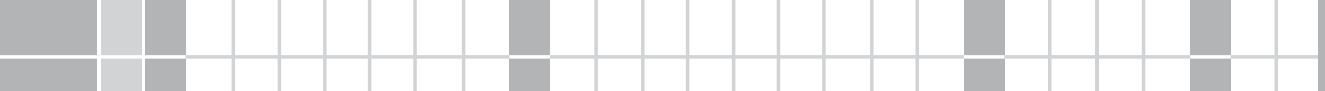

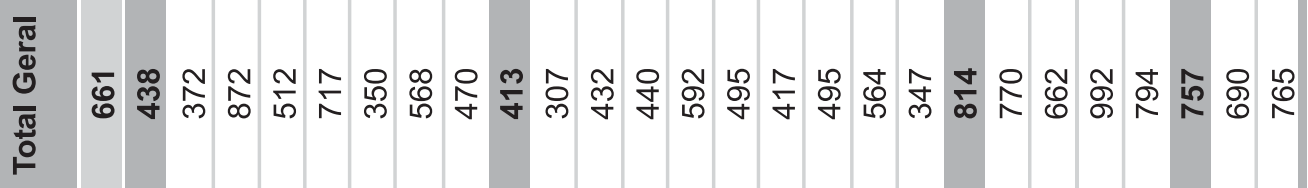

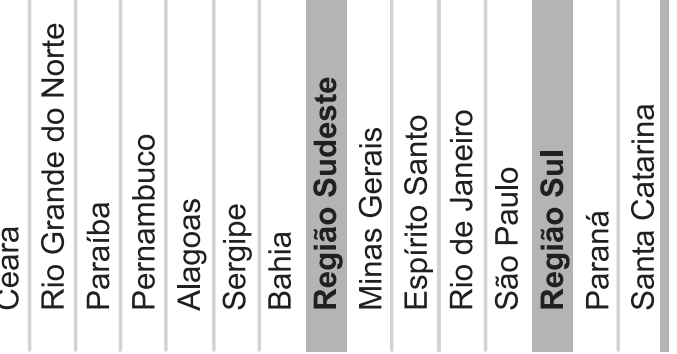




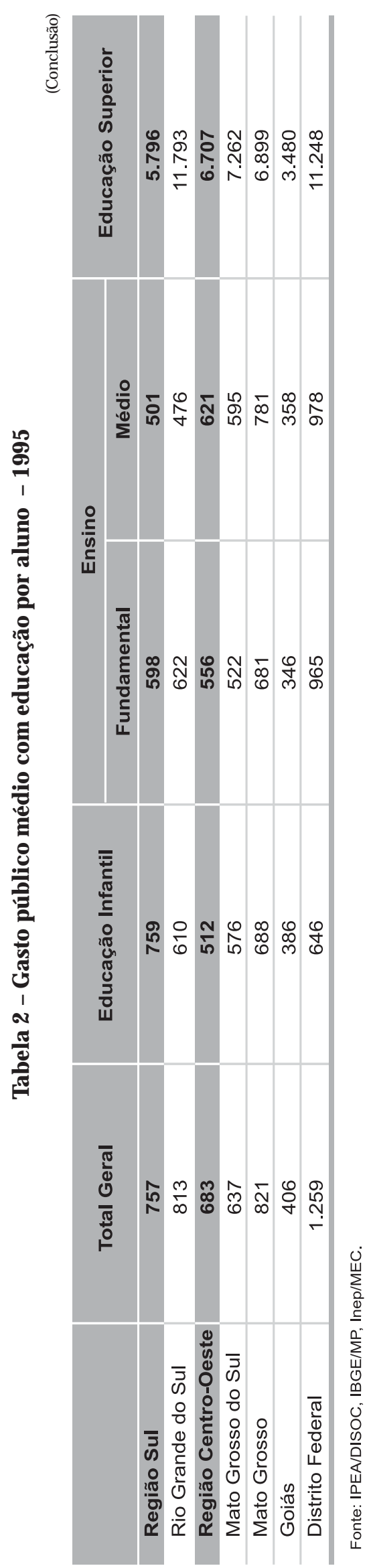




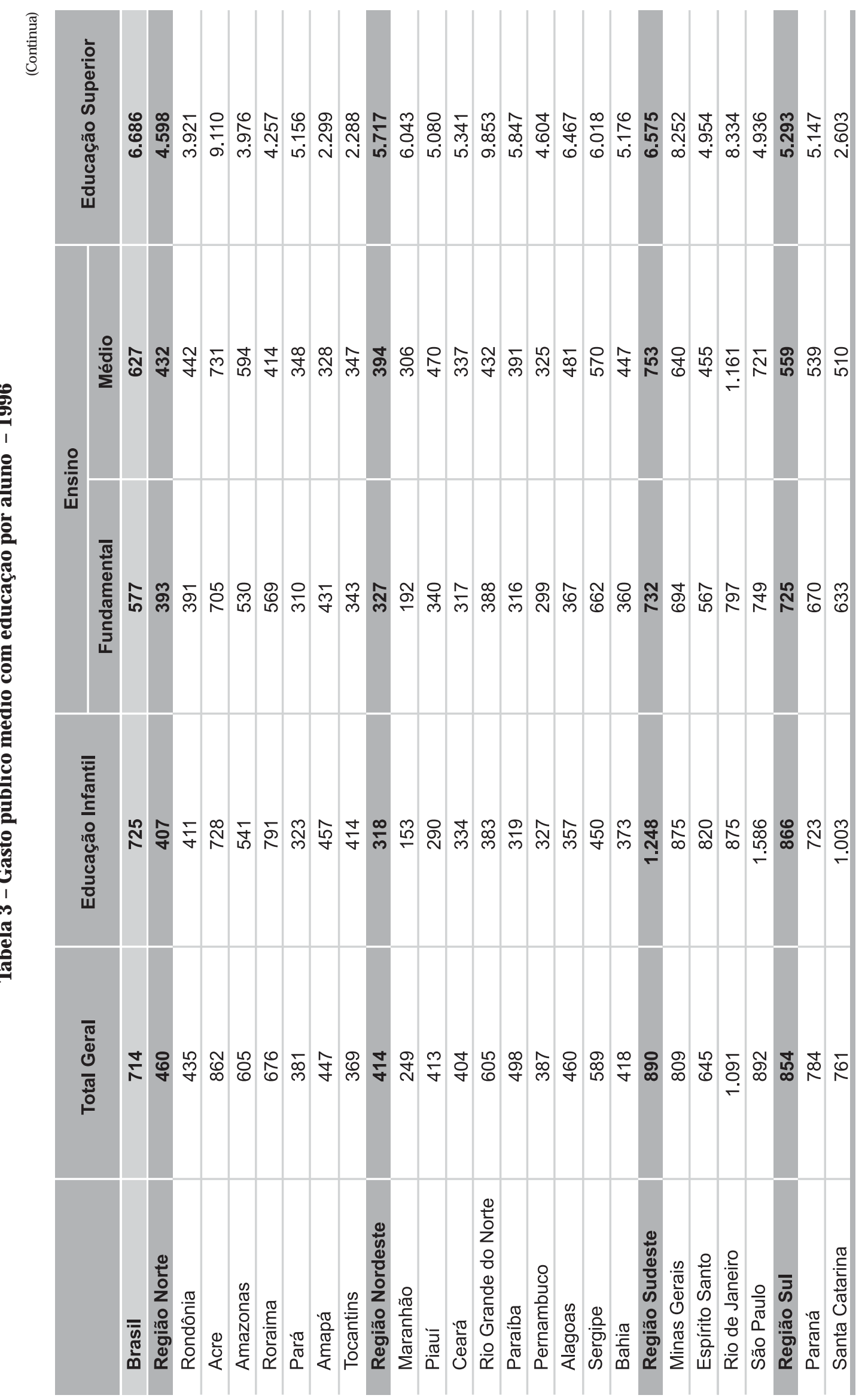




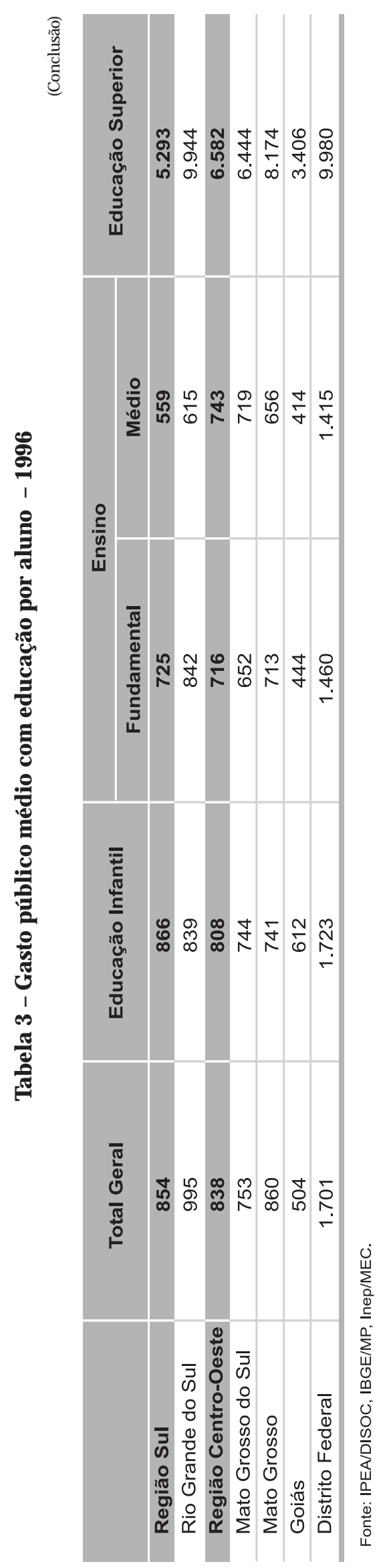


ஓ్లి の่

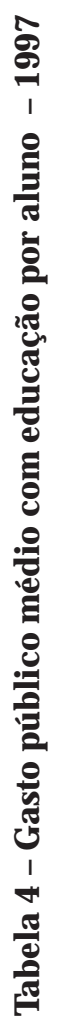

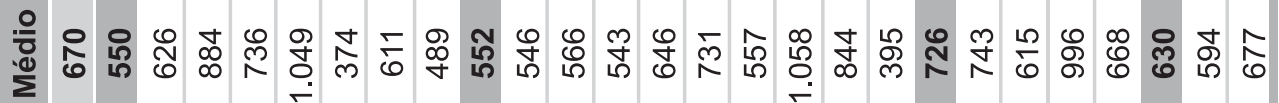

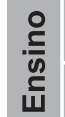

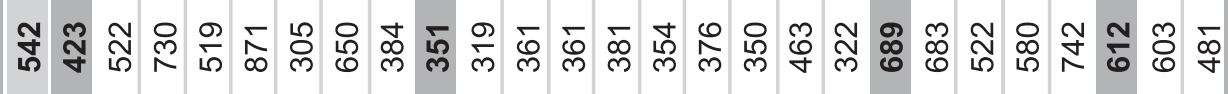

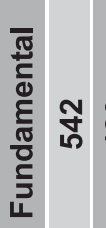

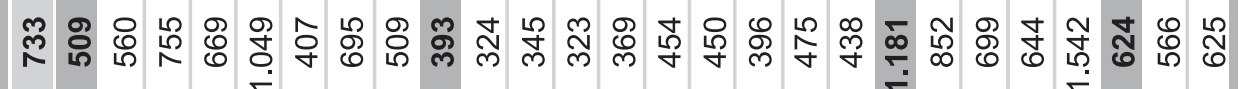

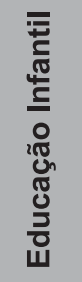

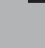

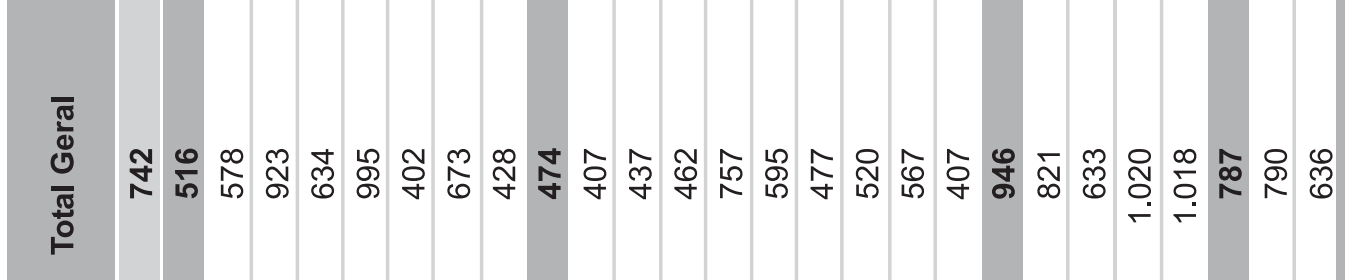

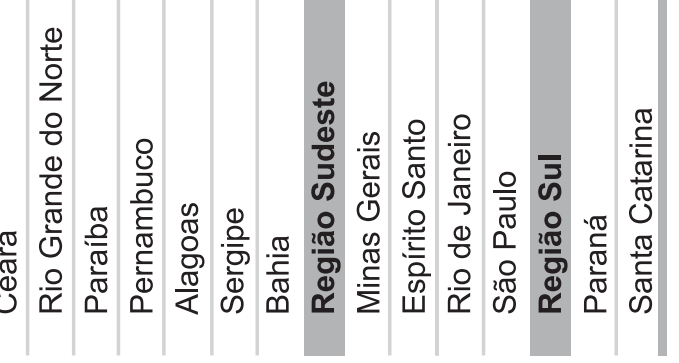




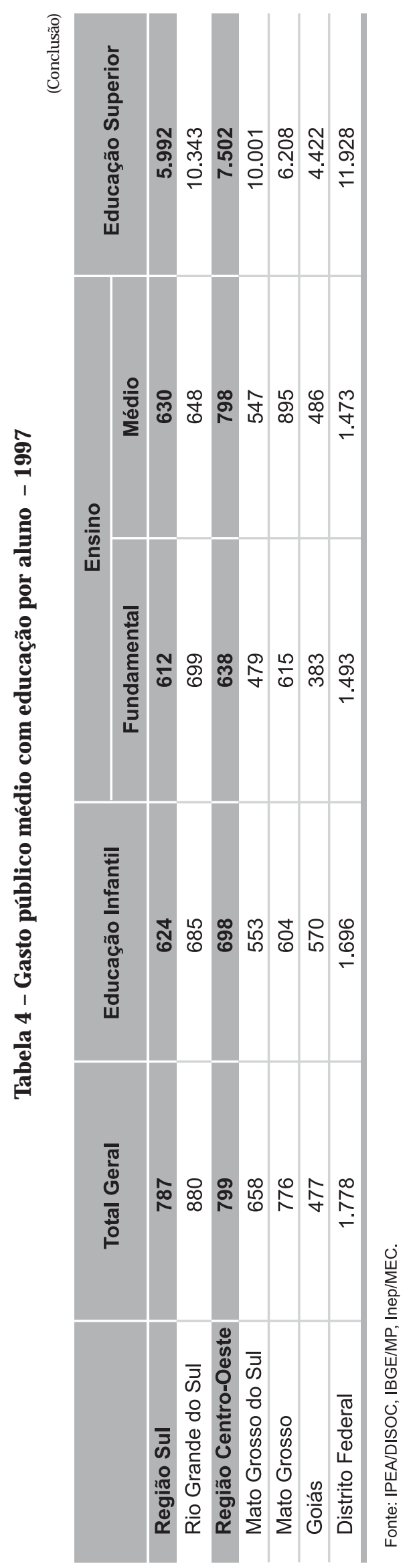


\&

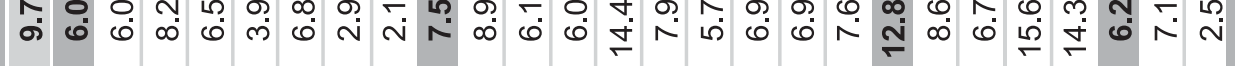

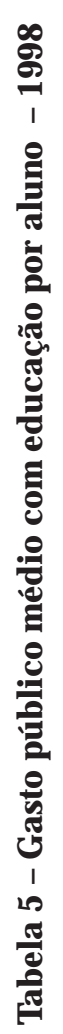

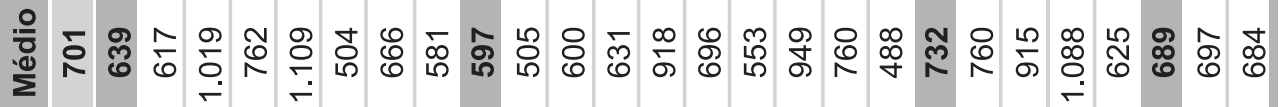

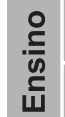

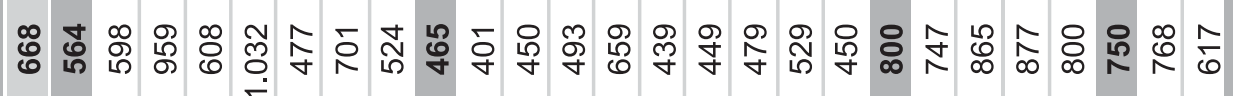
窝

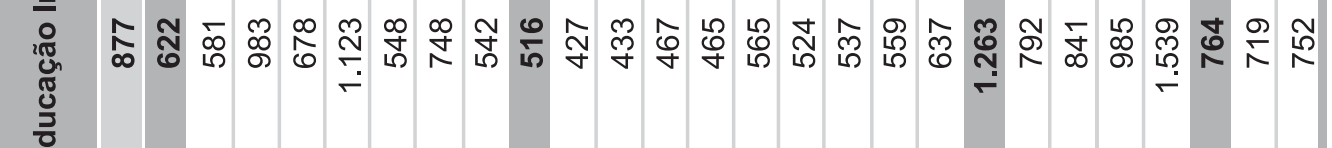
แ

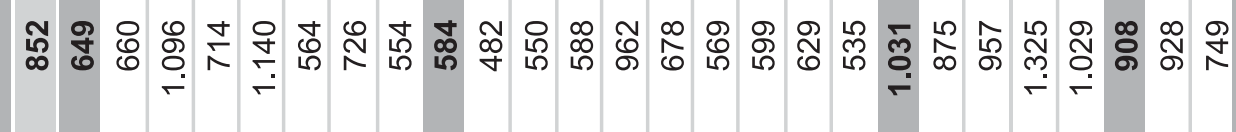

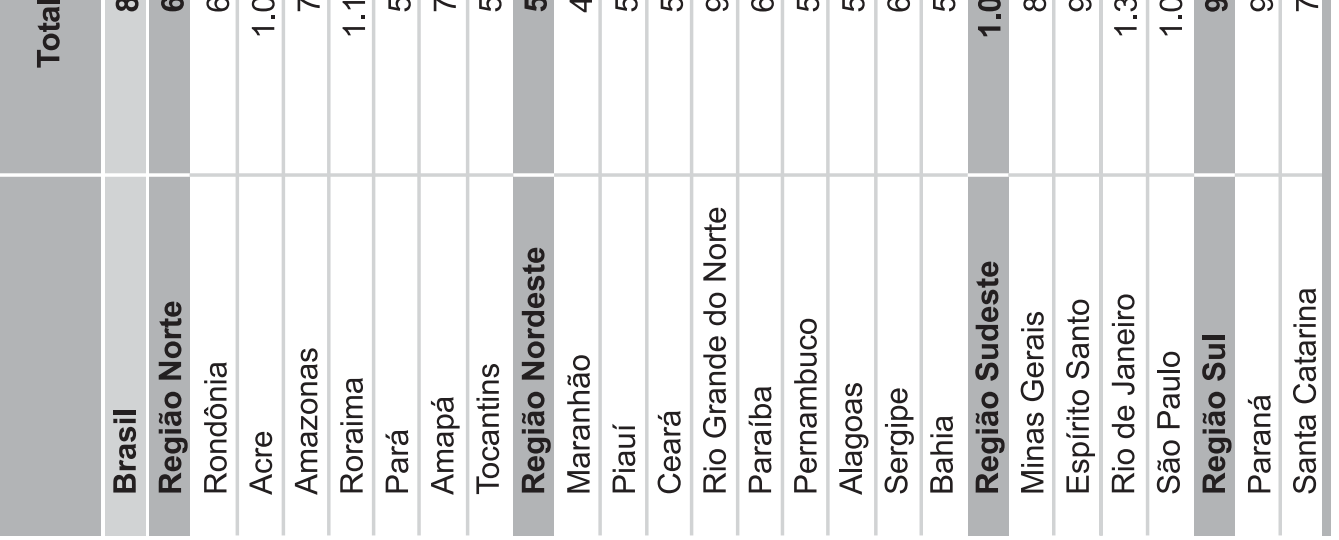




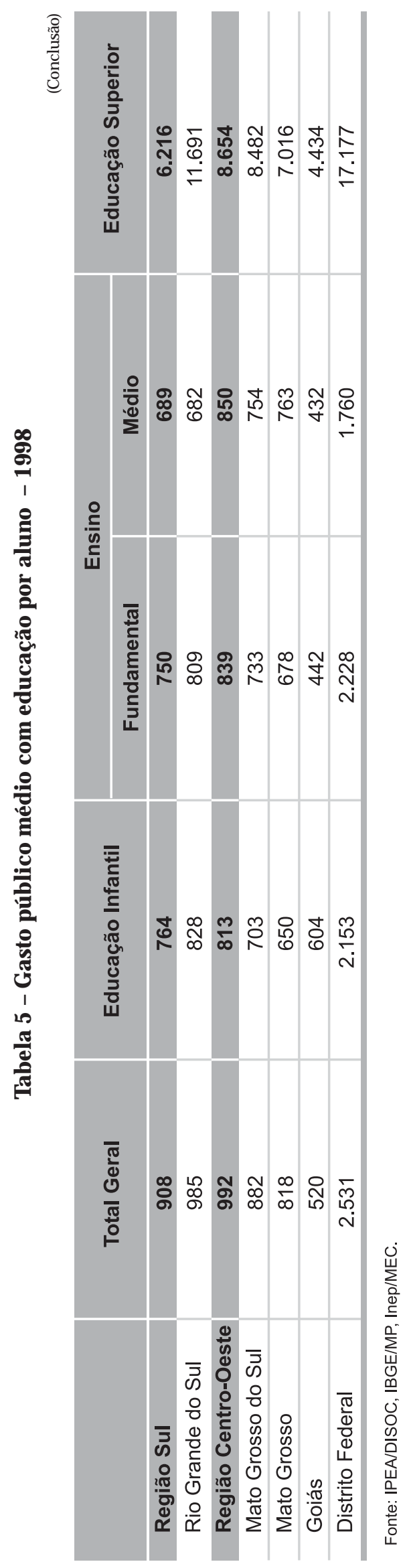


央 莳

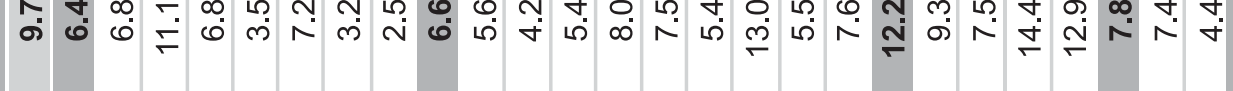

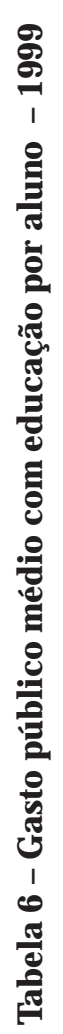

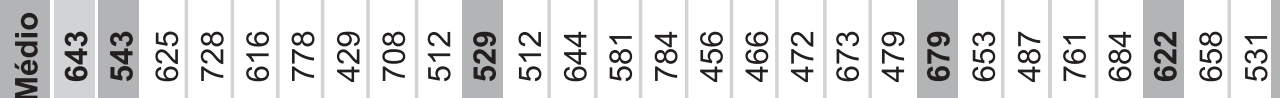

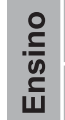

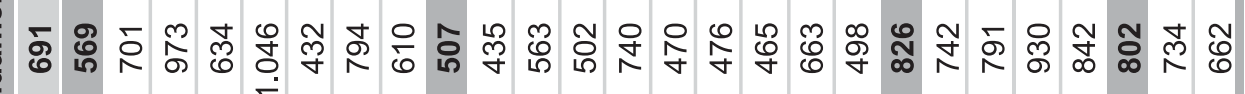
窝

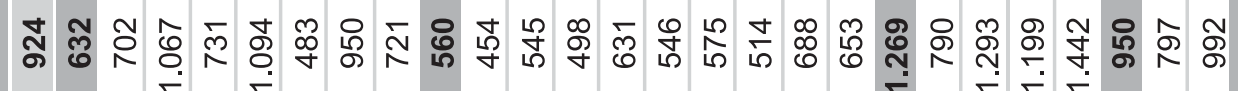

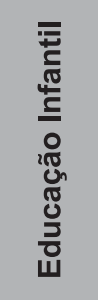

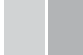

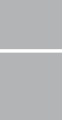

然

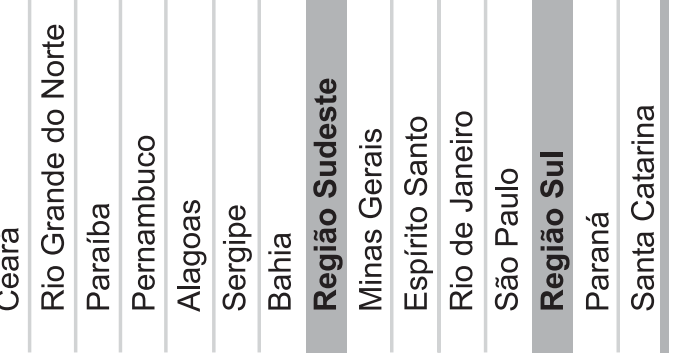




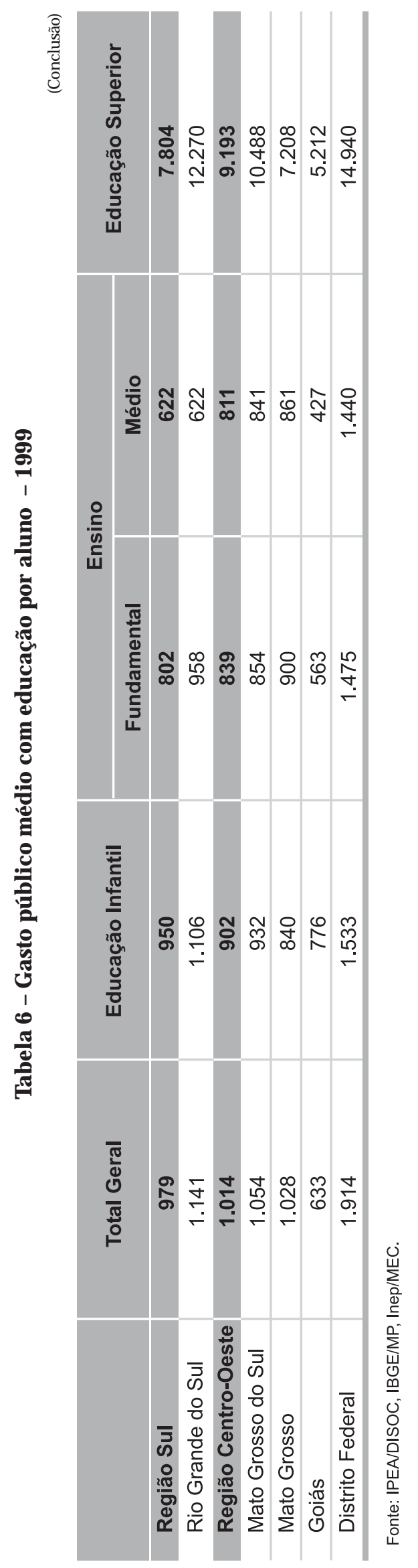




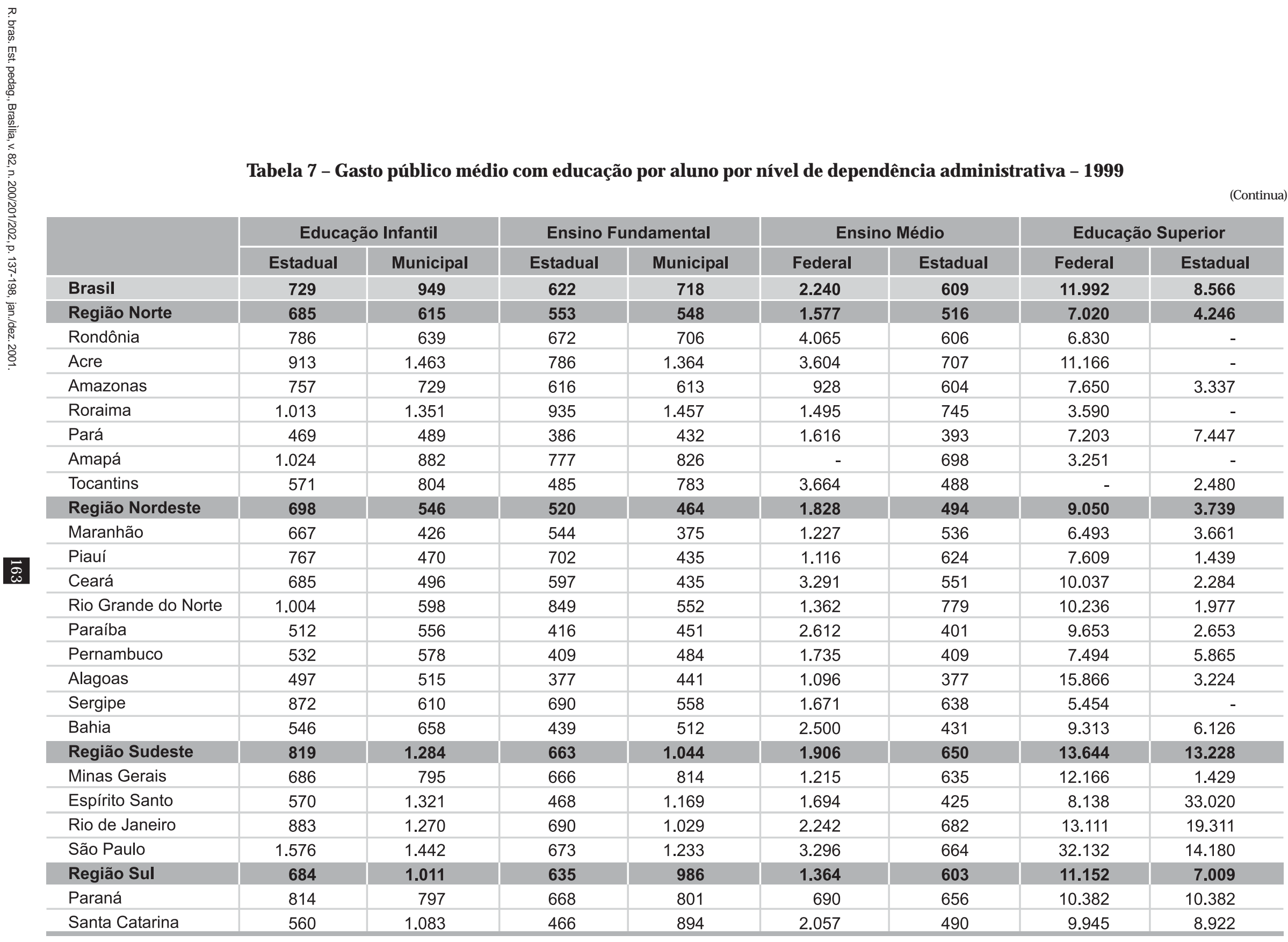


Tabela 7 - Gasto público médio por al uno com educação por nível de dependência administrativa - 1999

(Conclusão)

\begin{tabular}{|c|c|c|c|c|c|c|c|c|}
\hline & \multicolumn{2}{|c|}{ Educação Infantil } & \multicolumn{2}{|c|}{ Ensino Fundamental } & \multicolumn{2}{|c|}{ Ensino Médio } & \multicolumn{2}{|c|}{ Educação Superior } \\
\hline & Estadual & Municipal & Estadual & Municipal & Federal & Estadual & Federal & Estadual \\
\hline Região Sul & 684 & 1.011 & 635 & 986 & 1.364 & 603 & 11.152 & 7.009 \\
\hline Rio Grande do Sul & 729 & 1.362 & 706 & 1.248 & 1.664 & 592 & 11.996 & - \\
\hline Região Centro-Oeste & 837 & 935 & 759 & 835 & 4.864 & 740 & 11.724 & 2.292 \\
\hline Mato Grosso do Sul & 948 & 930 & 813 & 883 & 3.689 & 821 & 12.146 & 3.637 \\
\hline Mato Grosso & 982 & 830 & 892 & 830 & 2.363 & 819 & 9.072 & 3.285 \\
\hline Goiás & 410 & 994 & 369 & 815 & 2.194 & 382 & 8.827 & 1.403 \\
\hline
\end{tabular}

Fonte: IPEA/DISOC, IBGE/MP, Inep/MEC.

官

Nota: Gastos por nivel de ensino incluem todas as suas modalidades. 


\begin{tabular}{|c|c|c|c|c|c|}
\hline \multicolumn{6}{|c|}{ Tabela 8 - Despesa com educação por nível edependência admi nistrativa - 1994 (Em R\$1.000 correntes) } \\
\hline & Total Geral & Educação Infantil & Ensino Fundamental & Ensino Médio & Educação Superior \\
\hline Brasil & 13.554.768 & 1.270 .384 & 8.142 .956 & 1.262 .814 & 2.878.614 \\
\hline Federal & 3.314 .980 & 2.054 & 811.371 & 171.941 & 2.329 .615 \\
\hline Estadual & 6.461 .175 & 297.725 & 4.657 .442 & 1.004 .940 & 501.069 \\
\hline Municipal & 3.778 .612 & 970.605 & 2.674 .143 & 85.934 & 47.929 \\
\hline Região Norte & 794.033 & 71.178 & 486.654 & 60.488 & 175.714 \\
\hline Federal & 192.989 & 38.497 & 33.265 & 5.536 & 154.189 \\
\hline Estadual & 449.018 & 32.681 & 334.567 & 54.430 & 21.525 \\
\hline Municipal & 152.026 & & 118.822 & 522 & \\
\hline Rondônia & 55.678 & 4.046 & 40.086 & 4.314 & 7.231 \\
\hline Federal & 9.244 & & 1.742 & 271 & 7.231 \\
\hline Estadual & 32.186 & 2.594 & 25.615 & 3.978 & \\
\hline Municipal & 14.248 & 1.453 & 12.729 & 66 & \\
\hline Acre & 64.781 & 3.406 & 40.029 & 4.643 & 16.704 \\
\hline Federal & 17.522 & & 718 & 101 & 16.704 \\
\hline Estadual & 38.781 & 2.773 & 31.588 & 4.421 & \\
\hline Municipal & 8.477 & 633 & 7.723 & 122 & \\
\hline Amazonas & 169.197 & 17.215 & 100.426 & 12.304 & 39.253 \\
\hline Federal & 34.507 & & 7.848 & 1.393 & 25.266 \\
\hline Estadual & 96.017 & 9.650 & 61.468 & 10.911 & 13.988 \\
\hline Municipal & 38.673 & 7.564 & 31.109 & & \\
\hline Roraima & 26.925 & 3.862 & 17.182 & 1.794 & 4.088 \\
\hline Federal & 5.135 & & 940 & 107 & 4.088 \\
\hline Estadual & 18.162 & 1.652 & 14.823 & 1.687 & \\
\hline Municipal & 3.628 & 2.210 & 1.418 & & \\
\hline Pará & 366.385 & 33.532 & 202.475 & 25.454 & 104.923 \\
\hline Federal & 121.606 & & 19.532 & 3.249 & 98.825 \\
\hline Estadual & 176.172 & 15.631 & 132.416 & 22.027 & 6.098 \\
\hline Municipal & 68.607 & 17.902 & 50.528 & 178 & \\
\hline
\end{tabular}


Tabela 8 - Despesa com educação por nível edependência admi nistrativa - 1994 (Em R\$ 1.000 correntes)

(Continuação)

\begin{tabular}{|c|c|c|c|c|c|}
\hline & Total Geral & Educação Infantil & Ensino Fundamental & Ensino Médio & Educação Superior \\
\hline Amapá & 39.648 & 4.513 & 29.386 & 3.673 & 2.076 \\
\hline Federal & 2.512 & & 376 & 61 & 2.076 \\
\hline Estadual & 29.370 & 3.432 & 22.326 & 3.613 & \\
\hline Municipal & 7.766 & 1.081 & 6.685 & & \\
\hline Tocantins & 71.419 & 4.604 & 57.070 & 8.306 & 1.439 \\
\hline Federal & 2.463 & & 2.108 & 355 & \\
\hline Estadual & 58.330 & 2.765 & 46.332 & 7.794 & 1.439 \\
\hline Municipal & 10.626 & 1.839 & 8.630 & 157 & \\
\hline Região Nordeste & 2.340 .426 & 261.404 & 1.364 .223 & 166.711 & 548.089 \\
\hline Federal & 631.983 & & 156.498 & 26.571 & 448.914 \\
\hline Estadual & 1.057 .373 & 90.752 & 744.167 & 123.383 & 99.071 \\
\hline Municipal & 651.070 & 170.652 & 463.558 & 16.758 & 103 \\
\hline Maranhão & 238.793 & 20.845 & 148.519 & 20.035 & 49.394 \\
\hline Federal & 50.686 & & 12.351 & 2.221 & 36.114 \\
\hline Estadual & 130.791 & 9.565 & 91.492 & 16.454 & 13.280 \\
\hline Municipal & 57.316 & 11.281 & 44.676 & 1.359 & \\
\hline Piauí & 143.282 & 16.242 & 89.152 & 8.485 & 29.403 \\
\hline Federal & 39.426 & & 9.048 & 1.155 & 29.224 \\
\hline Estadual & 71.743 & 8.744 & 55.709 & 7.111 & 179 \\
\hline Municipal & 32.112 & 7.498 & 24.395 & 219 & \\
\hline Ceará & 362.305 & 63.927 & 194.864 & 23.505 & 80.009 \\
\hline Federal & 71.861 & & 17.547 & 3.177 & 51.137 \\
\hline Estadual & 166.859 & 18.203 & 101.423 & 18.361 & 28.872 \\
\hline Municipal & 123.585 & 45.724 & 75.893 & 1.968 & \\
\hline Rio Grande do Norte & 174.455 & 11.843 & 87.690 & 13.516 & 61.406 \\
\hline Federal & 70.720 & & 12.897 & 2.804 & 55.018 \\
\hline Estadual & 65.716 & 5.082 & 44.557 & 9.688 & 6.388 \\
\hline Municipal & 38.019 & 6.761 & 30.236 & 1.023 & \\
\hline
\end{tabular}




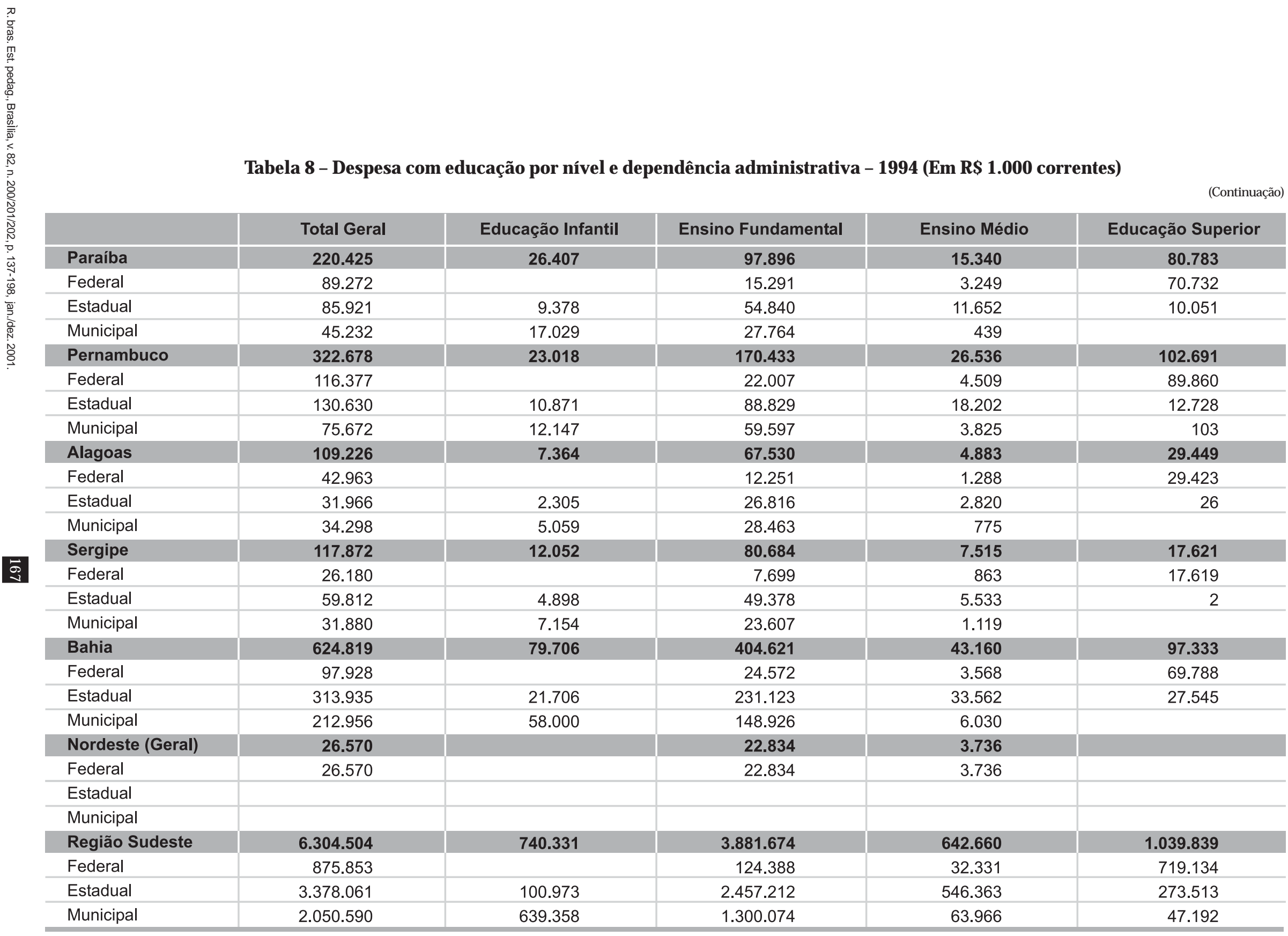


Tabela 8 - Despesa com educação por nível edependência admi nistrativa - 1994 (Em R\$ 1.000 correntes)

(Continuação)

\begin{tabular}{|c|c|c|c|c|c|}
\hline & Total Geral & Educação Infantil & Ensino Fundamental & Ensino Médio & Educação Superior \\
\hline Minas Gerais & 1.399 .226 & 105.138 & 907.955 & 104.653 & 281.481 \\
\hline Federal & 322.078 & & 38.899 & 5.582 & 277.597 \\
\hline Estadual & 657.491 & 43.123 & 534.505 & 76.695 & 3.168 \\
\hline Municipal & 419.658 & 62.015 & 334.551 & 22.376 & 716 \\
\hline Espírito Santo & 303.701 & 34.182 & 194.873 & 26.460 & 48.186 \\
\hline Federal & 60.004 & & 10.665 & 1.909 & 47.430 \\
\hline Estadual & 141.489 & 8.473 & 112.238 & 20.089 & 689 \\
\hline Municipal & 102.208 & 25.709 & 71.970 & 4.462 & 67 \\
\hline Rio de Janeiro & 1.249 .235 & 85.941 & 609.563 & 101.957 & 451.774 \\
\hline Federal & 373.972 & & 45.402 & 18.045 & 310.524 \\
\hline Estadual & 433.387 & 28.438 & 188.703 & 75.001 & 141.245 \\
\hline Municipal & 441.876 & 57.503 & 375.457 & 8.911 & 4 \\
\hline São Paulo & 3.352 .341 & 515.070 & 2.169 .284 & 409.590 & 258.398 \\
\hline Federal & 119.799 & & 29.422 & 6.795 & 83.582 \\
\hline Estadual & 2.145 .694 & 20.939 & 1.621 .766 & 374.578 & 128.411 \\
\hline Municipal & 1.086 .848 & 494.131 & 518.096 & 28.216 & 46.405 \\
\hline Região Sul & 2.248.399 & 149.948 & 1.429 .292 & 206.482 & 462.677 \\
\hline Federal & 418.889 & & 45.133 & 12.084 & 361.672 \\
\hline Estadual & 1.024 .439 & 35.233 & 697.816 & 191.019 & 100.371 \\
\hline Municipal & 805.071 & 114.715 & 686.343 & 3.378 & 635 \\
\hline Paraná & 815.182 & 39.602 & 543.941 & 82.268 & 149.371 \\
\hline Federal & 84.204 & & 11.859 & 4.343 & 68.003 \\
\hline Estadual & 373.321 & 1.779 & 212.390 & 77.784 & 81.368 \\
\hline Municipal & 357.656 & 37.824 & 319.692 & 141 & \\
\hline Santa Catarina & 500.858 & 67.444 & 291.905 & 43.753 & 97.756 \\
\hline Federal & 99.494 & & 14.100 & 3.208 & 82.187 \\
\hline Estadual & 239.791 & 12.865 & 172.332 & 39.203 & 15.391 \\
\hline Municipal & 161.573 & 54.579 & 105.472 & 1.343 & 177 \\
\hline
\end{tabular}


Tabela 8 - Despesa com educação por nível edependência administrativa - 1994 (Em R\$1.000 correntes)

(Conclusão)

\begin{tabular}{|c|c|c|c|c|c|}
\hline & Total Geral & Educação Infantil & Ensino Fundamental & Ensino Médio & Educação Superior \\
\hline Rio Grande do Sul & 932.359 & 42.902 & 593.446 & 80.461 & 215.551 \\
\hline Federal & 235.190 & & 19.174 & 4.534 & 211.482 \\
\hline Estadual & 411.327 & 20.589 & 313.093 & 74.033 & 3.612 \\
\hline Municipal & 285.842 & 22.312 & 261.179 & 1.894 & 457 \\
\hline Região Centro-Oeste & 916.791 & 45.469 & 550.805 & 95.669 & 224.848 \\
\hline Federal & 244.653 & & 21.779 & 4.614 & 218.259 \\
\hline Estadual & 552.284 & 32.271 & 423.679 & 89.745 & 6.589 \\
\hline Municipal & 119.855 & 13.199 & 105.347 & 1.310 & \\
\hline Mato Grosso do Sul & 163.287 & 8.447 & 103.474 & 18.961 & 32.404 \\
\hline Federal & 34.201 & & 1.428 & 369 & 32.404 \\
\hline Estadual & 89.912 & 3.870 & 68.390 & 17.652 & \\
\hline Municipal & 39.174 & 4.577 & 33.656 & 941 & \\
\hline Mato Grosso & 163.804 & 8.163 & 95.082 & 7.736 & 52.824 \\
\hline Federal & 58.897 & & 7.524 & 1.472 & 49.901 \\
\hline Estadual & 42.954 & 2.476 & 31.411 & 6.144 & 2.923 \\
\hline Municipal & 61.954 & 5.687 & 56.147 & 120 & \\
\hline Goiás & 195.949 & 10.700 & 121.850 & 23.579 & 39.821 \\
\hline Federal & 49.580 & & 11.009 & 2.416 & 36.155 \\
\hline Estadual & 127.642 & 7.765 & 95.297 & 20.914 & 3.666 \\
\hline Municipal & 18.727 & 2.935 & 15.543 & 248 & \\
\hline Distrito Federal & 393.751 & 18.159 & 230.399 & 45.393 & 99.800 \\
\hline Federal & 101.975 & & 1.817 & 358 & 99.800 \\
\hline Estadual & 291.776 & 18.159 & 228.582 & 45.035 & \\
\hline Nacional & 950.614 & 2.054 & 430.309 & 90.804 & 427.447 \\
\hline
\end{tabular}

Fonte: IPEA/DISOC, IBGE/MP, Inep/MEC.

Nota: Gastos por nivel de ensino incluem todas as suas modalidades. 
Tabela 9 - Despesa com educação por nível edependência admi nistrativa - 1995 (Em R\$ 1.000 correntes)

(Continua)

\begin{tabular}{|c|c|c|c|c|c|}
\hline & Total Geral & Educação Infantil & Ensino Fundamental & Ensino Médio & Educação Superior \\
\hline Brasil & 25.199.272 & 2.787 .294 & 14.952 .030 & 2.377 .893 & 5.082 .055 \\
\hline Federal & 5.081 .854 & & 877.614 & 196.036 & 4.008 .203 \\
\hline Estadual & 12.303 .117 & 547.871 & 8.782 .154 & 2.000 .725 & 972.367 \\
\hline Municipal & 7.814 .301 & 2.239 .423 & 5.292 .261 & 181.133 & 101.485 \\
\hline Região Norte & 1.489 .941 & 148.167 & 901.825 & 119.399 & 320.550 \\
\hline Federal & 363.743 & & 71.835 & 12.458 & 279.450 \\
\hline Estadual & 839.430 & 79.272 & 613.274 & 105.784 & 41.100 \\
\hline Municipal & 286.768 & 68.895 & 216.716 & 1.157 & \\
\hline Rondônia & 118.073 & 8.238 & 82.994 & 10.900 & 15.940 \\
\hline Federal & 20.068 & & 3.578 & 551 & 15.940 \\
\hline Estadual & 83.717 & 6.503 & 66.916 & 10.298 & \\
\hline Municipal & 14.287 & 1.736 & 12.500 & 52 & \\
\hline Acre & 122.816 & 7.043 & 75.241 & 9.471 & 31.062 \\
\hline Federal & 32.812 & & 1.523 & 228 & 31.062 \\
\hline Estadual & 75.087 & 5.664 & 60.394 & 9.029 & \\
\hline Municipal & 14.917 & 1.379 & 13.324 & 214 & \\
\hline Amazonas & 361.126 & 49.906 & 192.533 & 26.947 & 91.740 \\
\hline Federal & 73.712 & & 15.236 & 3.115 & 55.362 \\
\hline Estadual & 200.844 & 24.049 & 116.584 & 23.833 & 36.379 \\
\hline Municipal & 86.570 & 25.857 & 60.713 & & \\
\hline Roraima & 55.661 & 7.091 & 35.189 & 3.968 & 9.413 \\
\hline Federal & 14.653 & & 4.663 & 577 & 9.413 \\
\hline Estadual & 34.323 & 3.529 & 27.403 & 3.391 & \\
\hline Municipal & 6.685 & 3.562 & 3.123 & & \\
\hline Pará & 583.529 & 52.846 & 321.499 & 42.563 & 166.621 \\
\hline Federal & 208.091 & & 38.474 & 6.537 & 163.080 \\
\hline Estadual & 277.542 & 27.298 & 210.876 & 35.827 & 3.541 \\
\hline Municipal & 97.896 & 25.548 & 72.149 & 199 & \\
\hline
\end{tabular}




\begin{tabular}{|c|c|c|c|c|c|}
\hline \multicolumn{6}{|c|}{ Tabela 9 - Despesa com educação por nível edependência administrativa - 1995 (Em R\$1.000 correntes) } \\
\hline & Total Geral & Educação Infantil & Ensino Fundamental & Ensino Médio & Educação Superior \\
\hline Amapá & 72.179 & 8.278 & 52.952 & 6.356 & 4.594 \\
\hline Federal & 5.740 & & 981 & 165 & 4.594 \\
\hline Estadual & 49.169 & 6.153 & 36.826 & 6.191 & \\
\hline Municipal & 17.270 & 2.126 & 15.145 & & \\
\hline Tocantins & 172.747 & 14.764 & 138.144 & 18.658 & 1.180 \\
\hline Federal & 4.857 & & 4.107 & 750 & \\
\hline Estadual & 118.748 & 6.076 & 94.275 & 17.216 & 1.180 \\
\hline Municipal & 49.142 & 8.688 & 39.762 & 692 & \\
\hline Região Norte (Geral) & 3.810 & & 3.273 & 537 & \\
\hline Federal & 3.810 & & 3.273 & 537 & \\
\hline \multicolumn{6}{|l|}{ Estadual } \\
\hline \multicolumn{6}{|l|}{ Municipal } \\
\hline Região Nordeste & 4.803 .533 & 567.533 & 2.915 .639 & 345.132 & 975.229 \\
\hline Federal & 1.107 .613 & & 212.131 & 36.671 & 858.812 \\
\hline Estadual & 2.120 .911 & 179.946 & 1.560 .640 & 264.118 & 116.207 \\
\hline Municipal & 1.575 .008 & 387.587 & 1.142 .868 & 44.343 & 210 \\
\hline Maranhão & 474.122 & 44.461 & 290.138 & 34.489 & 105.033 \\
\hline Federal & 105.341 & & 17.548 & 3.035 & 84.758 \\
\hline Estadual & 225.606 & 15.721 & 161.649 & 27.961 & 20.275 \\
\hline Municipal & 143.174 & 28.740 & 110.941 & 3.492 & \\
\hline Piauí & 309.478 & 38.673 & 198.714 & 18.291 & 53.799 \\
\hline Federal & 67.475 & & 12.847 & 1.703 & 52.925 \\
\hline Estadual & 157.082 & 18.751 & 121.369 & 16.088 & 874 \\
\hline Municipal & 84.921 & 19.922 & 64.498 & 500 & \\
\hline Ceará & 717.757 & 127.686 & 441.338 & 53.751 & 94.982 \\
\hline Federal & 124.190 & & 25.795 & 4.541 & 93.854 \\
\hline Estadual & 339.554 & 40.463 & 253.538 & 44.635 & 917 \\
\hline Municipal & 254.013 & 87.222 & 162.006 & 4.575 & 210 \\
\hline
\end{tabular}


Tabela 9 - Despesa com educação por nível edependência admi nistrativa - 1995 (Em R\$ 1.000 correntes)

(Continuação)

\begin{tabular}{|c|c|c|c|c|c|}
\hline & Total Geral & Educação Infantil & Ensino Fundamental & Ensino Médio & Educação Superior \\
\hline Rio Grande do Norte & 381.317 & 29.841 & 192.384 & 26.561 & 132.531 \\
\hline Federal & 137.280 & & 18.554 & 3.997 & 114.730 \\
\hline Estadual & 141.106 & 10.537 & 92.782 & 19.986 & 17.801 \\
\hline Municipal & 102.931 & 19.304 & 81.049 & 2.578 & \\
\hline Paraíba & 423.519 & 57.438 & 169.189 & 21.026 & 175.866 \\
\hline Federal & 181.224 & & 20.161 & 4.219 & 156.845 \\
\hline Estadual & 122.418 & 12.930 & 74.812 & 15.655 & 19.021 \\
\hline Municipal & 119.877 & 44.508 & 74.216 & 1.152 & \\
\hline Pernambuco & 781.353 & 75.663 & 464.202 & 64.662 & 176.826 \\
\hline Federal & 190.055 & & 34.558 & 7.318 & 148.179 \\
\hline Estadual & 294.584 & 24.263 & 199.441 & 42.233 & 28.647 \\
\hline Municipal & 296.714 & 51.400 & 230.203 & 15.112 & \\
\hline Alagoas & 272.943 & 20.408 & 176.485 & 13.396 & 62.655 \\
\hline Federal & 80.701 & & 20.153 & 2.183 & 58.365 \\
\hline Estadual & 99.894 & 6.793 & 80.130 & 8.681 & 4.290 \\
\hline Municipal & 92.348 & 13.615 & 76.202 & 2.532 & \\
\hline Sergipe & 246.487 & 25.518 & 170.560 & 16.813 & 33.596 \\
\hline Federal & 47.690 & & 12.592 & 1.502 & 33.596 \\
\hline Estadual & 131.831 & 10.498 & 108.402 & 12.931 & \\
\hline Municipal & 66.966 & 15.020 & 49.567 & 2.380 & \\
\hline Bahia & 1.174 .156 & 147.845 & 793.422 & 92.949 & 139.940 \\
\hline Federal & 151.256 & & 30.718 & 4.979 & 115.559 \\
\hline Estadual & 608.835 & 39.989 & 468.517 & 75.948 & 24.381 \\
\hline Municipal & 414.065 & 107.856 & 294.187 & 12.022 & \\
\hline R. Nordeste (Geral) & 22.400 & & 19.206 & 3.193 & \\
\hline Federal & 22.400 & & 19.206 & 3.193 & \\
\hline \multicolumn{6}{|l|}{ Estadual } \\
\hline Municipal & & & & & \\
\hline
\end{tabular}




\begin{tabular}{|c|c|c|c|c|c|}
\hline \multicolumn{6}{|c|}{ Tabela 9- Despesa com educação por nível edependência administrativa - 1995 (Em R\$1.000 correntes) } \\
\hline & Total Geral & Educação Infantil & Ensino Fundamental & Ensino Médio & Educação Superior \\
\hline Região Sudeste & 12.460 .847 & 1.698 .847 & 7.502.391 & 1.358 .568 & 1.901 .041 \\
\hline Federal & 1.508 .424 & & 222.873 & 60.831 & 1.224 .720 \\
\hline Estadual & 6.793 .419 & 184.161 & 4.860 .515 & 1.173 .383 & 575.359 \\
\hline Municipal & 4.159 .004 & 1.514 .685 & 2.419 .003 & 124.353 & 100.962 \\
\hline Minas Gerais & 3.179 .537 & 249.178 & 2.153 .932 & 262.084 & 514.344 \\
\hline Federal & 572.493 & & 58.735 & 8.813 & 504.945 \\
\hline Estadual & 1.659 .422 & 92.054 & 1.355 .098 & 203.317 & 8.953 \\
\hline Municipal & 947.622 & 157.124 & 740.098 & 49.954 & 446 \\
\hline Espírito Santo & 470.175 & 55.561 & 310.029 & 43.553 & 61.031 \\
\hline Federal & 84.702 & & 20.044 & 3.785 & 60.873 \\
\hline Estadual & 219.163 & 13.232 & 173.085 & 32.686 & 159 \\
\hline Municipal & 166.310 & 42.329 & 116.899 & 7.081 & \\
\hline Rio de Janeiro & 2.386.347 & 220.433 & 1.156 .672 & 209.380 & 799.862 \\
\hline Federal & 686.434 & & 104.608 & 38.007 & 543.820 \\
\hline Estadual & 919.342 & 77.090 & 429.999 & 156.230 & 256.023 \\
\hline Municipal & 780.571 & 143.344 & 622.066 & 15.142 & 19 \\
\hline São Paulo & 6.409 .074 & 1.173 .674 & 3.869 .061 & 840.534 & 525.804 \\
\hline Federal & 149.081 & & 26.788 & 7.210 & 115.083 \\
\hline Estadual & 3.995 .492 & 1.786 & 2.902 .332 & 781.150 & 310.224 \\
\hline Municipal & 2.264 .500 & 1.171 .888 & 939.940 & 52.175 & 100.497 \\
\hline R. Sudeste (Geral) & 15.714 & & 12.697 & 3.017 & \\
\hline Federal & 15.714 & & 12.697 & 3.017 & \\
\hline \multicolumn{6}{|l|}{ Estadual } \\
\hline \multicolumn{6}{|l|}{ Municipal } \\
\hline Região Sul & 3.932 .137 & 273.739 & 2.386 .886 & 341.138 & 930.374 \\
\hline Federal & 839.467 & & 106.936 & 28.931 & 703.600 \\
\hline Estadual & 1.645 .542 & 50.374 & 1.063 .481 & 305.225 & 226.462 \\
\hline Municipal & 1.447 .128 & 223.365 & 1.216 .468 & 6.982 & 312 \\
\hline
\end{tabular}


Tabela 9 - Despesa com educação por nível edependência admi nistrativa - 1995 (Em R\$ 1.000 correntes)

(Continuação)

\begin{tabular}{|c|c|c|c|c|c|}
\hline & Total Geral & Educação Infantil & Ensino Fundamental & Ensino Médio & Educação Superior \\
\hline Paraná & 1.451 .610 & 62.237 & 904.570 & 149.968 & 334.835 \\
\hline Federal & 179.607 & & 19.669 & 7.228 & 152.709 \\
\hline Estadual & 715.717 & 3.257 & 387.815 & 142.519 & 182.126 \\
\hline Municipal & 556.286 & 58.981 & 497.086 & 220 & \\
\hline Santa Catarina & 897.415 & 139.319 & 516.962 & 71.431 & 169.702 \\
\hline Federal & 163.108 & & 27.661 & 6.606 & 128.841 \\
\hline Estadual & 380.563 & 19.557 & 258.499 & 61.738 & 40.769 \\
\hline Municipal & 353.744 & 119.763 & 230.803 & 3.087 & 92 \\
\hline Rio Grande do Sul & 1.560 .592 & 72.182 & 947.761 & 114.811 & 425.837 \\
\hline Federal & 474.232 & & 42.014 & 10.169 & 422.050 \\
\hline Estadual & 549.262 & 27.560 & 417.167 & 100.967 & 3.567 \\
\hline Municipal & 537.097 & 44.622 & 488.580 & 3.675 & 220 \\
\hline Região Sul (Geral) & 22.520 & & 17.593 & 4.927 & \\
\hline Federal & 22.520 & & 17.593 & 4.927 & \\
\hline \multicolumn{6}{|l|}{ Estadual } \\
\hline \multicolumn{6}{|l|}{ Municipal } \\
\hline Região Centro-Oeste & 1.782 .262 & 99.008 & 1.143 .653 & 190.876 & 348.724 \\
\hline Federal & 532.052 & & 162.204 & 34.364 & 335.484 \\
\hline Estadual & 903.816 & 54.118 & 684.244 & 152.214 & 13.240 \\
\hline Municipal & 346.393 & 44.890 & 297.205 & 4.298 & \\
\hline Mato Grosso do Sul & 304.482 & 18.204 & 199.614 & 33.620 & 53.045 \\
\hline Federal & 56.838 & & 2.986 & 807 & 53.045 \\
\hline Estadual & 151.217 & 6.530 & 113.920 & 30.767 & \\
\hline Municipal & 96.427 & 11.674 & 82.708 & 2.046 & \\
\hline Mato Grosso & 467.930 & 26.932 & 314.083 & 44.912 & 82.003 \\
\hline Federal & 94.404 & & 16.229 & 3.290 & 74.885 \\
\hline Estadual & 269.127 & 16.484 & 204.137 & 41.388 & 7.118 \\
\hline Municipal & 104.398 & 10.448 & 93.716 & 234 & \\
\hline
\end{tabular}


Tabela 9 - Despesa com educação por nível edependência admi nistrativa - 1995 (Em R\$1.000 correntes)

(Conclusão)

\begin{tabular}{|c|c|c|c|c|c|}
\hline & Total Geral & Educação Infantil & Ensino Fundamental & Ensino Médio & Educação Superior \\
\hline Goiás & 461.884 & 37.464 & 308.931 & 45.916 & 69.573 \\
\hline Federal & 87.316 & & 19.351 & 4.515 & 63.451 \\
\hline Estadual & 229.000 & 14.695 & 168.800 & 39.383 & 6.122 \\
\hline Municipal & 145.567 & 22.768 & 120.781 & 2.018 & \\
\hline Distrito Federal & 532.260 & 16.409 & 308.230 & 63.518 & 144.105 \\
\hline Federal & 277.788 & & 110.842 & 22.842 & 144.105 \\
\hline Estadual & 254.472 & 16.409 & 197.387 & 40.676 & \\
\hline \multicolumn{6}{|l|}{ Municipal } \\
\hline Centro-Oeste (Geral) & 15.706 & & 12.795 & 2.911 & \\
\hline Federal & 15.706 & & 12.795 & 2.911 & \\
\hline \multicolumn{6}{|l|}{ Estadual } \\
\hline \multicolumn{6}{|l|}{ Municipal } \\
\hline Nacional & 730.553 & & 101.635 & 22.781 & 606.137 \\
\hline
\end{tabular}

Fonte: IPEA/DISOC, IBGE/MP, Inep/MEC.

Nota: Gastos por nível de ensino incluem todas as suas modalidades. 
Tabela 10 - Despesa com educação por dependência administrativa - 1996 (Em R\$ 1.000 correntes)

(Continua)

\begin{tabular}{|c|c|c|c|c|c|}
\hline & Total Geral & Educação Infantil & Ensino Fundamental & Ensino Médio & Educação Superior \\
\hline Brasil & 29.672 .859 & 3.246 .396 & 18.160 .949 & 3.014 .781 & 5.250 .732 \\
\hline Federal & 5.039 .122 & 66 & 778.360 & 176.777 & 4.083 .919 \\
\hline Estadual & 15.226 .328 & 623.138 & 11.017 .287 & 2.625 .810 & 960.093 \\
\hline Municipal & 9.407.409 & 2.623 .192 & 6.365 .302 & 212.194 & 206.721 \\
\hline Região Norte & 1.753 .236 & 201.991 & 1.141 .520 & 153.266 & \\
\hline Federal & 323.034 & & 70.479 & 12.279 & 256.459 \\
\hline Estadual & 1.043 .805 & 104.268 & 783.996 & 139.358 & 240.276 \\
\hline Municipal & 386.397 & 97.723 & 287.046 & 1.628 & 16.183 \\
\hline Rondônia & 162.160 & 11.067 & 118.699 & 16.930 & \\
\hline Federal & 22.157 & & 5.698 & 995 & 15.464 \\
\hline Estadual & 114.298 & 8.283 & 90.256 & 15.759 & 15.464 \\
\hline Municipal & 25.704 & 2.784 & 22.744 & 176 & \\
\hline Acre & 137.358 & 8.725 & 90.767 & 11.447 & \\
\hline Federal & 28.805 & & 2.060 & 326 & 26.419 \\
\hline Estadual & 86.622 & 6.718 & 68.987 & 10.917 & 26.419 \\
\hline Municipal & 21.931 & 2.007 & 19.720 & 204 & \\
\hline Amazonas & 462.243 & 60.916 & 295.153 & 48.159 & \\
\hline Federal & 72.653 & & 16.369 & 3.435 & 58.014 \\
\hline Estadual & 295.671 & 33.723 & 212.239 & 44.543 & 52.848 \\
\hline Municipal & 93.919 & 27.193 & 66.545 & 181 & 5.166 \\
\hline Roraima & 63.320 & 8.179 & 39.120 & 4.977 & \\
\hline Federal & 17.626 & & 5.788 & 794 & 11.044 \\
\hline Estadual & 38.704 & 4.950 & 29.680 & 4.074 & 11.044 \\
\hline Municipal & 6.990 & 3.229 & 3.652 & 109 & \\
\hline Pará & 712.834 & 92.252 & 438.345 & 51.251 & 130.986 \\
\hline Federal & 166.942 & & 32.239 & 5.115 & 129.589 \\
\hline Estadual & 375.019 & 41.055 & 287.027 & 45.540 & 1.397 \\
\hline Municipal & 170.872 & 51.197 & 119.079 & 597 & \\
\hline
\end{tabular}




\begin{tabular}{|c|c|c|c|c|c|}
\hline \multicolumn{6}{|c|}{ Tabela 10- Despesa com educação por dependência administrativa - 1996 (Em R\$1.000 correntes) } \\
\hline & Total Geral & Educação Infantil & Ensino Fundamental & Ensino Médio & Educação Superior \\
\hline Amapá & 67.374 & 7.486 & 48.784 & 6.191 & 4.912 \\
\hline Federal & 6.657 & & 1.466 & 280 & 4.912 \\
\hline Estadual & 41.935 & 5.026 & 30.997 & 5.912 & \\
\hline Municipal & 18.782 & 2.460 & 16.322 & & \\
\hline Tocantins & 147.895 & 13.365 & 110.609 & 14.302 & 9.620 \\
\hline Federal & 8.141 & & 6.815 & 1.326 & \\
\hline Estadual & 91.556 & 4.512 & 64.810 & 12.614 & 9.620 \\
\hline Municipal & 48.198 & 8.853 & 38.984 & 362 & \\
\hline Região Norte (Geral) & 52 & & 44 & 8 & \\
\hline Federal & 52 & & 44 & 8 & \\
\hline \multicolumn{6}{|l|}{ Estadual } \\
\hline \multicolumn{6}{|l|}{ Municipal } \\
\hline Região Nordeste & 5.189 .072 & 577.197 & 3.128 .840 & 373.355 & 1.109 .680 \\
\hline Federal & 1.194 .697 & & 258.505 & 44.473 & 891.718 \\
\hline Estadual & 2.330 .910 & 172.811 & 1.688 .274 & 283.096 & 186.729 \\
\hline Municipal & 1.663 .465 & 404.386 & 1.182 .061 & 45.785 & 31.233 \\
\hline Maranhão & 408.041 & 42.826 & 239.685 & 29.057 & 96.473 \\
\hline Federal & 98.316 & & 20.589 & 3.438 & 74.289 \\
\hline Estadual & 193.439 & 13.389 & 135.277 & 22.589 & 22.184 \\
\hline Municipal & 116.286 & 29.437 & 83.819 & 3.030 & \\
\hline Piauí & 337.086 & 38.067 & 213.817 & 20.538 & 64.664 \\
\hline Federal & 85.212 & & 18.900 & 2.234 & 64.077 \\
\hline Estadual & 192.052 & 21.763 & 151.763 & 17.939 & 587 \\
\hline Municipal & 59.822 & 16.303 & 43.154 & 364 & \\
\hline Ceará & 751.722 & 105.581 & 440.123 & 42.343 & 163.675 \\
\hline Federal & 147.501 & & 37.571 & 6.168 & 103.762 \\
\hline Estadual & 286.030 & 14.161 & 182.066 & 29.890 & 59.913 \\
\hline Municipal & 318.191 & 91.419 & 220.486 & 6.285 & \\
\hline
\end{tabular}


Tabela 10 - Despesa com educação por dependência administrativa - 1996 (Em R\$ 1.000 correntes)

(Continuação)

\begin{tabular}{|c|c|c|c|c|c|}
\hline & Total Geral & Educação Infantil & Ensino Fundamental & Ensino Médio & Educação Superior \\
\hline Rio Grande do Norte & 422.271 & 28.998 & 208.017 & 30.768 & 154.488 \\
\hline Federal & 144.087 & & 20.440 & 4.187 & 119.459 \\
\hline Estadual & 189.281 & 11.929 & 118.124 & 24.199 & 35.029 \\
\hline Municipal & 88.903 & 17.068 & 69.453 & 2.382 & \\
\hline Paraíba & 460.072 & 61.687 & 199.410 & 27.931 & 171.044 \\
\hline Federal & 184.126 & & 26.586 & 5.869 & 151.671 \\
\hline Estadual & 147.756 & 15.151 & 92.755 & 20.478 & 19.373 \\
\hline Municipal & 128.190 & 46.536 & 80.070 & 1.584 & \\
\hline Pernambuco & 780.971 & 65.598 & 468.402 & 68.624 & 178.347 \\
\hline Federal & 197.940 & & 44.559 & 9.460 & 143.920 \\
\hline Estadual & 318.368 & 20.429 & 217.364 & 46.148 & 34.427 \\
\hline Municipal & 264.663 & 45.169 & 206.479 & 13.015 & \\
\hline Alagoas & 277.363 & 23.953 & 182.706 & 14.162 & 56.542 \\
\hline Federal & 79.931 & & 21.116 & 2.324 & 56.492 \\
\hline Estadual & 105.981 & 7.719 & 88.476 & 9.736 & 50 \\
\hline Municipal & 91.451 & 16.234 & 73.114 & 2.103 & \\
\hline Sergipe & 275.674 & 26.883 & 242.709 & 19.980 & 37.735 \\
\hline Federal & 55.424 & & 17.284 & 1.951 & 37.735 \\
\hline Estadual & 151.691 & 11.791 & 136.696 & 15.432 & \\
\hline Municipal & 68.559 & 15.092 & 88.729 & 2.596 & \\
\hline Bahia & 1.466 .567 & 183.606 & 977.609 & 118.640 & 186.712 \\
\hline Federal & 192.855 & & 45.012 & 7.530 & 140.313 \\
\hline Estadual & 746.313 & 56.478 & 577.984 & 96.685 & 15.166 \\
\hline Municipal & 527.399 & 127.128 & 354.614 & 14.425 & 31.233 \\
\hline R. Nordeste (Geral) & 9.305 & & 7.994 & 1.312 & \\
\hline Federal & 9.305 & & 7.994 & 1.312 & \\
\hline \multicolumn{6}{|l|}{ Estadual } \\
\hline Municipal & & & & & \\
\hline
\end{tabular}




\begin{tabular}{|c|c|c|c|c|c|}
\hline \multicolumn{6}{|c|}{ Tabela 10- Despesa com educação por dependência admi nistrativa - 1996 (Em R\$ 1.000 correntes) } \\
\hline & Total Geral & Educação Infantil & Ensino Fundamental & Ensino Médio & Educação Superior \\
\hline Região Sudeste & 14.794 .507 & 1.968 .447 & 9.087 .996 & 1.747 .958 & 1.990 .106 \\
\hline Federal & 1.602 .939 & & 226.375 & 64.485 & 1.312 .079 \\
\hline Estadual & 8.232 .078 & 192.157 & 5.995 .523 & 1.535 .443 & 508.955 \\
\hline Municipal & 4.959 .490 & 1.776 .290 & 2.866 .098 & 148.030 & 169.072 \\
\hline Minas Gerais & 3.615 .581 & 303.553 & 2.479 .492 & 309.225 & 523.312 \\
\hline Federal & 570.963 & & 55.025 & 8.681 & 507.258 \\
\hline Estadual & 1.823 .056 & 52.510 & 1.516 .357 & 239.216 & 14.973 \\
\hline Municipal & 1.221 .562 & 251.043 & 908.110 & 61.328 & 1.081 \\
\hline Espírito Santo & 497.212 & 60.902 & 329.297 & 47.512 & 59.501 \\
\hline Federal & 93.028 & & 28.232 & 5.549 & 59.246 \\
\hline Estadual & 221.511 & 12.300 & 174.631 & 34.325 & 255 \\
\hline Municipal & 182.672 & 48.602 & 126.434 & 7.637 & \\
\hline Rio de Janeiro & 2.879 .776 & 283.767 & 1.524 .377 & 370.940 & 700.693 \\
\hline Federal & 729.739 & & 106.937 & 40.385 & 582.417 \\
\hline Estadual & 1.393 .789 & 126.360 & 835.027 & 315.348 & 117.054 \\
\hline Municipal & 756.248 & 157.407 & 582.413 & 15.207 & 1.222 \\
\hline São Paulo & 7.801 .938 & 1.320 .226 & 4.754 .830 & 1.020 .282 & 706.601 \\
\hline Federal & 209.209 & & 36.180 & 9.871 & 163.158 \\
\hline Estadual & 4.793 .722 & 987 & 3.469 .508 & 946.553 & 376.673 \\
\hline Municipal & 2.799 .008 & 1.319 .238 & 1.249 .142 & 63.858 & 166.769 \\
\hline Região Sul & 4.811 .514 & 333.312 & 3.094 .044 & 451.515 & 932.643 \\
\hline Federal & 807.954 & & 95.811 & 26.390 & 685.753 \\
\hline Estadual & 2.137 .963 & 67.422 & 1.414 .877 & 415.190 & 240.474 \\
\hline Municipal & 1.865 .596 & 265.890 & 1.583 .356 & 9.934 & 6.416 \\
\hline Paraná & 1.828 .859 & 81.870 & 1.191 .276 & 200.282 & 355.431 \\
\hline Federal & 180.661 & & 21.324 & 8.062 & 151.275 \\
\hline Estadual & 906.013 & 5.071 & 505.620 & 191.166 & 204.156 \\
\hline Municipal & 742.185 & 76.799 & 664.333 & 1.053 & \\
\hline
\end{tabular}


Tabela 10 - Despesa com educação por dependência admi nistrativa - 1996 (Em R\$1.000 correntes)

(Continuação)

\begin{tabular}{|c|c|c|c|c|c|}
\hline & Total Geral & Educação Infantil & Ensino Fundamental & Ensino Médio & Educação Superior \\
\hline Santa Catarina & 983.908 & 145.443 & 584.240 & 81.073 & 173.152 \\
\hline Federal & 182.337 & & 35.357 & 8.663 & 138.317 \\
\hline Estadual & 403.276 & 20.330 & 279.603 & 68.508 & 34.835 \\
\hline Municipal & 398.295 & 125.113 & 269.280 & 3.901 & \\
\hline Rio Grande do Sul & 1.998 .747 & 106.000 & 1.318 .527 & 170.160 & 404.060 \\
\hline Federal & 444.956 & & 39.131 & 9.665 & 396.161 \\
\hline Estadual & 828.674 & 42.022 & 629.653 & 155.515 & 1.483 \\
\hline Municipal & 725.117 & 63.978 & 649.743 & 4.980 & 6.416 \\
\hline Região Centro-Oeste & 2.479 .140 & 165.383 & 1.663 .026 & 278.354 & 372.377 \\
\hline Federal & 465.108 & & 81.667 & 18.816 & 364.625 \\
\hline Estadual & 1.481 .571 & 86.480 & 1.134 .617 & 252.723 & 7.752 \\
\hline Municipal & 532.461 & 78.904 & 446.742 & 6.816 & \\
\hline Mato Grosso do Sul & 389.122 & 24.444 & 269.651 & 44.790 & 50.238 \\
\hline Federal & 66.022 & & 12.428 & 3.356 & 50.238 \\
\hline Estadual & 190.208 & 8.117 & 143.376 & 38.715 & \\
\hline Municipal & 132.892 & 16.327 & 113.846 & 2.719 & \\
\hline Mato Grosso & 523.798 & 27.676 & 348.487 & 46.607 & 101.028 \\
\hline Federal & 140.160 & & 33.235 & 7.151 & 99.774 \\
\hline Estadual & 230.838 & 11.400 & 179.551 & 38.633 & 1.254 \\
\hline Municipal & 152.800 & 16.276 & 135.701 & 823 & \\
\hline Goiás & 653.944 & 65.298 & 451.047 & 63.845 & 73.754 \\
\hline Federal & 100.693 & & 26.996 & 6.442 & 67.256 \\
\hline Estadual & 306.481 & 18.997 & 226.856 & 54.130 & 6.498 \\
\hline Municipal & 246.769 & 46.301 & 197.194 & 3.274 & \\
\hline Distrito Federal & 912.277 & 47.966 & 593.841 & 123.113 & 147.357 \\
\hline Federal & 158.233 & & 9.008 & 1.868 & 147.357 \\
\hline Estadual & 754.044 & 47.966 & 584.833 & 121.245 & \\
\hline Municipal & & & & & \\
\hline
\end{tabular}


R. bras. Est. pedag., Braslia, v. 82, n. 200/201/202, p. 137-198, jan./dez. 2001.R. bras. Est. pedag., Brasilia, v. 82, n. 200/201/202, p. 137-198, jan./dez. 2001.

Tabela 10 - Despesa com educação por dependência admi nistrativa - 1996 (Em R\$1.000 correntes)

\begin{tabular}{|c|c|c|c|c|c|}
\hline & Total Geral & Educação Infantil & Ensino Fundamental & Ensino Médio & Educação Superior \\
\hline Nacional & 645.390 & 66 & 45.523 & 10.333 & 589.467 \\
\hline
\end{tabular}

Nota: Gastos por nível de ensino incluem todas as suas modalidades. 
Tabela 11 - Despesa com educação por dependência admi nistrativa - 1997 (Em R\$1.000 correntes)

(Continua)

\begin{tabular}{|c|c|c|c|c|c|}
\hline & Total Geral & Educação Infantil & Ensino Fundamental & Ensino Médio & Educação Superior \\
\hline Brasil & 32.504 .836 & 3.453 .466 & 17.789 .894 & 3.655 .588 & 7.605 .888 \\
\hline Federal & 5.627 .909 & 4.064 & 383.929 & 504.464 & 4.735 .452 \\
\hline Estadual & 15.803 .794 & 465.337 & 9.861 .570 & 2.847 .342 & 2.629 .544 \\
\hline Municipal & 11.073 .133 & 2.984 .065 & 7.544 .395 & 303.781 & 240.892 \\
\hline Região Norte & 2.131 .580 & 263.632 & 1.332 .073 & 226.751 & 309.125 \\
\hline Federal & 353.672 & 616 & 32.133 & 45.303 & 275.619 \\
\hline Estadual & 1.151 .824 & 96.710 & 843.075 & 178.533 & 33.506 \\
\hline Municipal & 626.085 & 166.306 & 456.864 & 2.915 & 0 \\
\hline Rondônia & 222.766 & 16.678 & 161.244 & 26.474 & 18.370 \\
\hline Federal & 23.105 & 9 & 2.707 & 2.019 & 18.370 \\
\hline Estadual & 148.987 & 10.858 & 114.458 & 23.671 & 0 \\
\hline Municipal & 50.674 & 5.811 & 44.079 & 784 & 0 \\
\hline Acre & 171.513 & 11.012 & 109.203 & 15.943 & 35.355 \\
\hline Federal & 36.835 & 21 & 1.457 & 1 & 35.355 \\
\hline Estadual & 107.425 & 8.361 & 83.440 & 15.624 & 0 \\
\hline Municipal & 27.254 & 2.630 & 24.306 & 318 & 0 \\
\hline Amazonas & 502.903 & 67.688 & 308.840 & 63.623 & 62.753 \\
\hline Federal & 80.940 & 82 & 5.657 & 16.966 & 58.235 \\
\hline Estadual & 269.214 & 19.780 & 198.400 & 46.517 & 4.518 \\
\hline Municipal & 152.749 & 47.827 & 104.783 & 140 & 0 \\
\hline Roraima & 104.673 & 11.931 & 65.929 & 15.901 & 10.912 \\
\hline Federal & 18.221 & 30 & 1.257 & 6.021 & 10.912 \\
\hline Estadual & 80.946 & 9.696 & 61.372 & 9.878 & 0 \\
\hline Municipal & 5.506 & 2.204 & 3.299 & 2 & 0 \\
\hline Pará & 832.298 & 124.481 & 475.464 & 67.240 & 165.113 \\
\hline Federal & 182.551 & 449 & 16.759 & 18.100 & 147.243 \\
\hline Estadual & 336.552 & 30.627 & 240.087 & 47.968 & 17.870 \\
\hline Municipal & 313.195 & 93.405 & 218.618 & 1.172 & 0 \\
\hline
\end{tabular}




\begin{tabular}{|c|c|c|c|c|c|}
\hline \multicolumn{6}{|c|}{ Tabela 11 - Despesa com educação por dependência admi nistrativa - 1997 (Em R\$1.000 correntes) } \\
\hline & Total Geral & Educação Infantil & Ensino Fundamental & Ensino Médio & Educação Superior \\
\hline Amapá & 120.116 & 13.852 & 85.541 & 15.222 & 5.501 \\
\hline Federal & 6.495 & 9 & 968 & 16 & 5.501 \\
\hline Estadual & 97.057 & 11.363 & 70.489 & 15.205 & 0 \\
\hline Municipal & 16.564 & 2.480 & 14.084 & 0 & 0 \\
\hline Tocantins & 177.312 & 17.990 & 125.852 & 22.349 & 11.121 \\
\hline Federal & 5.526 & 16 & 3.328 & 2.179 & 3 \\
\hline Estadual & 111.643 & 6.025 & 74.830 & 19.670 & 11.118 \\
\hline Municipal & 60.143 & 11.949 & 47.694 & 500 & 0 \\
\hline Região Nordeste & 6.476 .848 & 705.442 & 3.704 .688 & 610.093 & 1.456 .625 \\
\hline Federal & 1.411 .795 & 774 & 118.368 & 145.952 & 1.146 .702 \\
\hline Estadual & 2.679 .013 & 147.741 & 1.852 .927 & 377.942 & 300.403 \\
\hline Municipal & 2.386 .040 & 556.927 & 1.733 .394 & 86.199 & 9.520 \\
\hline Maranhão & 735.497 & 91.825 & 444.486 & 61.781 & 137.405 \\
\hline Federal & 142.376 & 44 & 14.260 & 14.179 & 113.894 \\
\hline Estadual & 245.225 & 15.585 & 171.140 & 35.543 & 22.958 \\
\hline Municipal & 347.896 & 76.197 & 259.086 & 12.060 & 553 \\
\hline Piauí & 373.368 & 41.777 & 243.591 & 25.829 & 62.170 \\
\hline Federal & 68.701 & 50 & 7.850 & 8.753 & 52.049 \\
\hline Estadual & 164.821 & 12.157 & 126.734 & 16.005 & 9.925 \\
\hline Municipal & 139.845 & 29.571 & 109.007 & 1.072 & 196 \\
\hline Ceará & 968.507 & 102.416 & 570.987 & 88.602 & 206.501 \\
\hline Federal & 178.964 & 4 & 20.839 & 17.324 & 140.798 \\
\hline Estadual & 449.320 & 16.820 & 304.166 & 62.914 & 65.420 \\
\hline Municipal & 340.223 & 85.592 & 245.982 & 8.365 & 283 \\
\hline Rio Grande do Norte & 582.916 & 29.363 & 225.660 & 50.483 & 277.410 \\
\hline Federal & 280.584 & 194 & 5.214 & 14.824 & 260.352 \\
\hline Estadual & 198.228 & 7.735 & 141.263 & 32.324 & 16.906 \\
\hline Municipal & 104.105 & 21.434 & 79.183 & 3.336 & 152 \\
\hline
\end{tabular}


Tabela 11 - Despesa com educação por dependência admi nistrativa - 1997 (Em R\$1.000 correntes)

(Continuação)

\begin{tabular}{|c|c|c|c|c|c|}
\hline & Total Geral & Educação Infantil & Ensino Fundamental & Ensino Médio & Educação Superior \\
\hline Paraíba & 606.808 & 74.240 & 263.711 & 60.746 & 208.111 \\
\hline Federal & 217.134 & 32 & 8.624 & 21.763 & 186.715 \\
\hline Estadual & 224.732 & 17.818 & 149.340 & 36.414 & 21.160 \\
\hline Municipal & 164.941 & 56.390 & 105.746 & 2.569 & 235 \\
\hline Pernambuco & 1.007 .591 & 87.222 & 617.446 & 127.955 & 174.968 \\
\hline Federal & 168.946 & 182 & 19.546 & 30.314 & 118.903 \\
\hline Estadual & 427.734 & 13.893 & 291.071 & 73.353 & 49.417 \\
\hline Municipal & 410.911 & 73.147 & 306.829 & 24.287 & 6.648 \\
\hline Alagoas & 351.060 & 28.067 & 196.732 & 33.697 & 92.564 \\
\hline Federal & 112.482 & 37 & 5.671 & 18.390 & 88.385 \\
\hline Estadual & 91.793 & 5.439 & 73.066 & 9.325 & 3.964 \\
\hline Municipal & 146.784 & 22.591 & 117.995 & 5.983 & 215 \\
\hline Sergipe & 290.442 & 35.122 & 181.054 & 34.591 & 39.675 \\
\hline Federal & 55.806 & 0 & 4.530 & 11.700 & 39.576 \\
\hline Estadual & 149.736 & 13.727 & 116.262 & 19.747 & 0 \\
\hline Municipal & 84.900 & 21.395 & 60.262 & 3.144 & 99 \\
\hline Bahia & 1.560 .660 & 215.409 & 961.021 & 126.409 & 257.821 \\
\hline Federal & 186.801 & 232 & 31.833 & 8.706 & 146.030 \\
\hline Estadual & 727.424 & 44.569 & 479.884 & 92.318 & 110.653 \\
\hline Municipal & 646.435 & 170.608 & 449.304 & 25.385 & 1.138 \\
\hline Região Sudeste & 16.055 .153 & 2.062 .829 & 8.488 .675 & 1.893 .246 & 3.610 .402 \\
\hline Federal & 1.815 .855 & 1.566 & 122.310 & 202.755 & 1.489 .224 \\
\hline Estadual & 8.180 .618 & 86.216 & 4.698 .555 & 1.494 .954 & 1.900 .893 \\
\hline Municipal & 6.058 .680 & 1.975 .047 & 3.667 .810 & 195.537 & 220.285 \\
\hline Minas Gerais & 3.821 .691 & 310.014 & 2.496 .517 & 420.042 & 595.118 \\
\hline Federal & 646.356 & 133 & 29.948 & 48.567 & 567.708 \\
\hline Estadual & 1.851 .126 & 20.642 & 1.505 .305 & 298.324 & 26.854 \\
\hline Municipal & 1.324 .209 & 289.238 & 961.264 & 73.151 & 555 \\
\hline
\end{tabular}




\begin{tabular}{|c|c|c|c|c|c|}
\hline \multicolumn{6}{|c|}{ Tabela 11 - Despesa com educação por dependência admi nistrativa - 1997 (Em R\$1.000 correntes) } \\
\hline & Total Geral & Educação Infantil & Ensino Fundamental & Ensino Médio & Educação Superior \\
\hline Espírito Santo & 515.721 & 62.787 & 311.789 & 70.759 & 70.386 \\
\hline Federal & 97.170 & 49 & 4.722 & 23.904 & 68.495 \\
\hline Estadual & 216.744 & 10.790 & 165.118 & 38.995 & 1.841 \\
\hline Municipal & 201.807 & 51.948 & 141.949 & 7.860 & 49 \\
\hline Rio de Janeiro & 2.764.391 & 218.063 & 1.120 .954 & 352.410 & 1.072 .963 \\
\hline Federal & 839.687 & 1.384 & 36.590 & 115.760 & 685.953 \\
\hline Estadual & 1.110 .615 & 53.638 & 462.576 & 214.683 & 379.718 \\
\hline Municipal & 814.089 & 163.042 & 621.788 & 21.966 & 7.293 \\
\hline São Paulo & 8.953 .350 & 1.471 .965 & 4.559 .415 & 1.050 .035 & 1.871 .935 \\
\hline Federal & 232.642 & 1 & 51.049 & 14.524 & 167.068 \\
\hline Estadual & 5.002 .133 & 1.145 & 2.565 .556 & 942.951 & 1.492 .480 \\
\hline Municipal & 3.718 .576 & 1.470 .819 & 1.942 .809 & 92.560 & 212.388 \\
\hline Região Sul & 4.683 .637 & 268.726 & 2.705 .308 & 574.253 & 1.135 .350 \\
\hline Federal & 858.395 & 933 & 41.670 & 57.107 & 758.685 \\
\hline Estadual & 2.326 .545 & 57.287 & 1.394 .735 & 508.586 & 365.937 \\
\hline Municipal & 1.498 .697 & 210.507 & 1.268 .902 & 8.560 & 10.728 \\
\hline Paraná & 1.929 .815 & 82.330 & 1.091 .958 & 243.168 & 512.359 \\
\hline Federal & 212.704 & 350 & 18.276 & 4.857 & 189.221 \\
\hline Estadual & 1.110 .046 & 5.070 & 545.259 & 237.726 & 321.991 \\
\hline Municipal & 607.065 & 76.910 & 528.423 & 585 & 1.146 \\
\hline Santa Catarina & 866.145 & 95.747 & 459.857 & 122.731 & 187.809 \\
\hline Federal & 181.553 & 463 & 8.522 & 24.510 & 148.058 \\
\hline Estadual & 388.944 & 17.826 & 239.141 & 94.585 & 37.392 \\
\hline Municipal & 295.648 & 77.458 & 212.194 & 3.636 & 2.359 \\
\hline Rio Grande do Sul & 1.887 .677 & 90.649 & 1.153 .492 & 208.354 & 435.182 \\
\hline Federal & 464.137 & 119 & 14.872 & 27.740 & 421.406 \\
\hline Estadual & 827.555 & 34.391 & 610.335 & 176.275 & 6.554 \\
\hline Municipal & 595.985 & 56.139 & 528.285 & 4.338 & 7.222 \\
\hline
\end{tabular}


Tabela 11 - Despesa com educação por dependência admi nistrativa - 1997 (Em R\$1.000 correntes)

(Conclusão)

\begin{tabular}{|c|c|c|c|c|c|}
\hline & Total Geral & Educação Infantil & Ensino Fundamental & Ensino Médio & Educação Superior \\
\hline Região Centro-Oeste & 2.462 .093 & 152.837 & 1.521 .369 & 332.380 & 455.507 \\
\hline Federal & 492.669 & 174 & 31.667 & 34.485 & 426.342 \\
\hline Estadual & 1.465 .793 & 77.384 & 1.072 .278 & 287.326 & 28.805 \\
\hline Municipal & 503.631 & 75.278 & 417.424 & 10.570 & 359 \\
\hline Mato Grosso do Sul & 355.628 & 21.193 & 203.106 & 37.250 & 94.079 \\
\hline Federal & 90.957 & 12 & 3.780 & 54 & 87.111 \\
\hline Estadual & 139.618 & 5.704 & 93.337 & 33.692 & 6.885 \\
\hline Municipal & 125.053 & 15.477 & 105.989 & 3.503 & 84 \\
\hline Mato Grosso & 532.205 & 28.055 & 332.984 & 73.434 & 97.731 \\
\hline Federal & 106.103 & 75 & 5.226 & 14.960 & 85.843 \\
\hline Estadual & 293.443 & 13.346 & 211.826 & 56.480 & 11.792 \\
\hline Municipal & 132.659 & 14.635 & 115.933 & 1.995 & 96 \\
\hline Goiás & 632.947 & 62.803 & 391.549 & 83.996 & 94.599 \\
\hline Federal & 111.585 & 33 & 8.335 & 18.926 & 84.291 \\
\hline Estadual & 275.442 & 17.603 & 187.713 & 59.998 & 10.128 \\
\hline Municipal & 245.919 & 45.167 & 195.501 & 5.071 & 180 \\
\hline Distrito Federal & 941.313 & 40.786 & 593.729 & 137.701 & 169.098 \\
\hline Federal & 184.023 & 54 & 14.326 & 545 & 169.098 \\
\hline Estadual & 757.290 & 40.731 & 579.403 & 137.156 & 0 \\
\hline Municipal & 0 & 0 & 0 & 0 & 0 \\
\hline Nacional & 695.524 & 1 & 37.781 & 18.864 & 638.879 \\
\hline Federal & 695.524 & 1 & 37.781 & 18.864 & 638.879 \\
\hline Estadual & 0 & 0 & 0 & 0 & 0 \\
\hline Municipal & 0 & 0 & 0 & 0 & 0 \\
\hline
\end{tabular}

Fonte: IPEA/DISOC, IBGE/MP, Inep/MEC

Nota: Gastos por nível de ensino incluem todas as suas modalidades. 


\begin{tabular}{|c|c|c|c|c|c|}
\hline \multicolumn{6}{|c|}{ Tabela 12 - Despesa com educação por dependência administrativa - 1998 (Em R\$1.000 correntes) } \\
\hline & Total Geral & Educação Infantil & Ensino Fundamental & Ensino Médio & Educação Superior \\
\hline Brasil & 38.747 .245 & 3.469 .403 & 23.089 .765 & 4.310 .375 & 7.877.701 \\
\hline Federal & 6.318 .714 & 142 & 869.946 & 509.824 & 4.938 .803 \\
\hline Estadual & 18.418 .480 & 357.252 & 11.724 .903 & 3.553 .736 & 2.782 .588 \\
\hline Municipal & 14.010 .050 & 3.112 .009 & 10.494 .916 & 246.815 & 156.309 \\
\hline Região Norte & 2.777 .666 & 245.376 & 1.914 .688 & 275.837 & 341.765 \\
\hline Federal & 387.932 & 0 & 47.830 & 43.253 & 296.850 \\
\hline Estadual & 1.406 .161 & 89.877 & 1.043 .713 & 229.841 & 42.730 \\
\hline Municipal & 983.572 & 155.499 & 823.146 & 2.744 & 2.185 \\
\hline Rondônia & 263.360 & 16.021 & 191.789 & 28.281 & 27.269 \\
\hline Federal & 34.282 & 0 & 4.775 & 2.252 & 27.254 \\
\hline Estadual & 162.656 & 9.292 & 127.945 & 25.419 & 0 \\
\hline Municipal & 66.422 & 6.729 & 59.069 & 610 & 15 \\
\hline Acre & 217.068 & 13.538 & 152.856 & 21.739 & 28.935 \\
\hline Federal & 31.607 & 0 & 2.677 & 0 & 28.930 \\
\hline Estadual & 153.501 & 11.039 & 121.018 & 21.444 & 0 \\
\hline Municipal & 31.959 & 2.499 & 29.161 & 295 & 5 \\
\hline Amazonas & 608.022 & 60.036 & 402.525 & 67.796 & 77.664 \\
\hline Federal & 94.065 & 0 & 9.682 & 16.371 & 68.013 \\
\hline Estadual & 311.943 & 17.399 & 233.596 & 51.325 & 9.623 \\
\hline Municipal & 202.014 & 42.637 & 159.248 & 101 & 29 \\
\hline Roraima & 129.366 & 14.991 & 81.860 & 19.440 & 13.075 \\
\hline Federal & 20.683 & 0 & 1.402 & 6.207 & 13.074 \\
\hline Estadual & 100.342 & 11.210 & 75.899 & 13.233 & 0 \\
\hline Municipal & 8.341 & 3.782 & 4.559 & 0 & 0 \\
\hline Pará & 1.183 .874 & 111.228 & 807.359 & 88.780 & 176.507 \\
\hline Federal & 192.613 & 0 & 23.555 & 15.948 & 153.110 \\
\hline Estadual & 407.222 & 24.231 & 287.806 & 71.996 & 23.190 \\
\hline Municipal & 584.039 & 86.997 & 495.999 & 836 & 207 \\
\hline
\end{tabular}


Tabela 12 - Despesa com educação por dependência admi nistrativa - 1998 (Em R\$1.000 correntes)

(Continuação)

\begin{tabular}{|c|c|c|c|c|c|}
\hline & Total Geral & Educação Infantil & Ensino Fundamental & Ensino Médio & Educação Superior \\
\hline Amapá & 138.318 & 12.538 & 101.006 & 18.306 & 6.468 \\
\hline Federal & 8.068 & 0 & 1.603 & 0 & 6.465 \\
\hline Estadual & 114.170 & 9.574 & 86.290 & 18.306 & 0 \\
\hline Municipal & 16.080 & 2.964 & 13.113 & 0 & 3 \\
\hline Tocantins & 237.601 & 17.024 & 177.234 & 31.496 & 11.846 \\
\hline Federal & 6.557 & 0 & 4.078 & 2.475 & 4 \\
\hline Estadual & 156.327 & 7.133 & 111.159 & 28.119 & 9.917 \\
\hline Municipal & 74.717 & 9.892 & 61.998 & 902 & 1.926 \\
\hline Região Norte (Geral) & 59 & 0 & 59 & 0 & 0 \\
\hline Federal & 59 & 0 & 59 & 0 & 0 \\
\hline Estadual & 0 & 0 & 0 & 0 & 0 \\
\hline Municipal & 0 & 0 & 0 & 0 & 0 \\
\hline Região Nordeste & 8.417 .093 & 668.927 & 5.409 .486 & 754.557 & 1.584 .123 \\
\hline Federal & 1.514 .605 & 0 & 190.755 & 150.480 & 1.173 .370 \\
\hline Estadual & 3.240 .009 & 82.653 & 2.251 .291 & 512.472 & 393.593 \\
\hline Municipal & 3.662 .479 & 586.273 & 2.967 .440 & 91.605 & 17.161 \\
\hline Maranhão & 924.841 & 91.740 & 622.100 & 67.279 & 143.722 \\
\hline Federal & 114.949 & 0 & 23.511 & 13.056 & 78.381 \\
\hline Estadual & 306.239 & 14.736 & 189.299 & 39.003 & 63.200 \\
\hline Municipal & 503.653 & 77.004 & 409.289 & 15.220 & 2.140 \\
\hline Piauí & 493.412 & 40.293 & 330.171 & 32.671 & 90.277 \\
\hline Federal & 97.939 & 0 & 11.807 & 9.606 & 76.526 \\
\hline Estadual & 191.544 & 13.763 & 143.221 & 21.565 & 12.995 \\
\hline Municipal & 203.930 & 26.530 & 175.144 & 1.499 & 757 \\
\hline Ceará & 1.272 .212 & 113.209 & 841.361 & 115.720 & 201.923 \\
\hline Federal & 192.006 & 0 & 31.171 & 18.864 & 141.971 \\
\hline Estadual & 473.993 & 3.602 & 325.128 & 87.319 & 57.944 \\
\hline Municipal & 606.213 & 109.607 & 485.062 & 9.536 & 2.008 \\
\hline
\end{tabular}




\begin{tabular}{|c|c|c|c|c|c|}
\hline \multicolumn{6}{|c|}{ Tabela 12 - Despesa com educação por dependência admi nistrativa - 1998 (Em R\$1.000 correntes) } \\
\hline & Total Geral & Educação Infantil & Ensino Fundamental & Ensino Médio & Educação Superior \\
\hline Rio Grande do Norte & 797.959 & 36.102 & 425.265 & 82.395 & 254.197 \\
\hline Federal & 270.693 & 0 & 15.170 & 18.386 & 237.137 \\
\hline Estadual & 357.923 & 7.082 & 274.345 & 60.014 & 16.481 \\
\hline Municipal & 169.343 & 29.019 & 135.749 & 3.995 & 579 \\
\hline Paraíba & 724.501 & 60.877 & 371.064 & 59.815 & 232.745 \\
\hline Federal & 243.755 & 0 & 18.756 & 19.530 & 205.469 \\
\hline Estadual & 243.757 & 12.494 & 168.404 & 36.439 & 26.420 \\
\hline Municipal & 236.989 & 48.383 & 183.904 & 3.846 & 856 \\
\hline Pernambuco & 1.248 .653 & 89.089 & 776.437 & 139.651 & 243.476 \\
\hline Federal & 224.563 & 0 & 27.878 & 31.857 & 164.829 \\
\hline Estadual & 476.961 & 3.087 & 316.037 & 86.806 & 71.032 \\
\hline Municipal & 547.129 & 86.002 & 432.522 & 20.989 & 7.616 \\
\hline Alagoas & 454.798 & 30.536 & 312.989 & 36.011 & 75.262 \\
\hline Federal & 99.195 & 0 & 10.395 & 19.058 & 69.743 \\
\hline Estadual & 112.262 & 2.537 & 92.774 & 12.243 & 4.709 \\
\hline Municipal & 243.341 & 28.000 & 209.821 & 4.710 & 811 \\
\hline Sergipe & 351.587 & 43.708 & 225.117 & 36.934 & 45.828 \\
\hline Federal & 63.811 & 0 & 6.730 & 11.617 & 45.464 \\
\hline Estadual & 167.834 & 16.031 & 128.095 & 23.707 & 0 \\
\hline Municipal & 119.942 & 27.677 & 90.292 & 1.609 & 364 \\
\hline Bahia & 2.149 .128 & 163.372 & 1.504 .983 & 184.082 & 296.691 \\
\hline Federal & 207.694 & 0 & 45.337 & 8.507 & 153.850 \\
\hline Estadual & 909.497 & 9.322 & 613.989 & 145.376 & 140.811 \\
\hline Municipal & 1.031 .937 & 154.051 & 845.657 & 30.199 & 2.031 \\
\hline Região Sudeste & 17.909 .025 & 2.065 .498 & 9.995 .875 & 2.166 .802 & 3.680 .850 \\
\hline Federal & 1.930 .486 & 0 & 117.438 & 207.388 & 1.605 .659 \\
\hline Estadual & 9.135 .421 & 52.503 & 5.317 .651 & 1.821 .632 & 1.943 .635 \\
\hline Municipal & 6.843 .118 & 2.012 .995 & 4.560 .785 & 137.782 & 131.556 \\
\hline
\end{tabular}


Tabela 12 - Despesa com educação por dependência administrativa - 1998 (Em R\$ 1.000 correntes)

(Continuação)

\begin{tabular}{|c|c|c|c|c|c|}
\hline & Total Geral & Educação Infantil & Ensino Fundamental & Ensino Médio & Educação Superior \\
\hline Minas Gerais & 4.162 .921 & 267.168 & 2.773 .009 & 482.156 & 640.588 \\
\hline Federal & 677.393 & 0 & 16.779 & 49.370 & 611.244 \\
\hline Estadual & 1.981 .194 & 10.055 & 1.549 .605 & 392.191 & 29.344 \\
\hline Municipal & 1.504 .334 & 257.113 & 1.206 .625 & 40.596 & 0 \\
\hline Espírito Santo & 804.544 & 68.408 & 531.158 & 121.751 & 83.227 \\
\hline Federal & 108.479 & 0 & 8.731 & 23.367 & 76.382 \\
\hline Estadual & 410.076 & 7.764 & 307.015 & 93.738 & 1.558 \\
\hline Municipal & 285.990 & 60.644 & 215.412 & 4.646 & 5.288 \\
\hline Rio de Janeiro & 3.689 .417 & 253.387 & 1.783 .523 & 453.332 & 1.199 .175 \\
\hline Federal & 940.427 & 0 & 80.003 & 122.487 & 737.937 \\
\hline Estadual & 1.464 .200 & 34.590 & 659.922 & 308.450 & 461.238 \\
\hline Municipal & 1.284 .790 & 218.798 & 1.043 .598 & 22.395 & 0 \\
\hline São Paulo & 9.252 .142 & 1.476 .535 & 4.908 .185 & 1.109 .562 & 1.757 .860 \\
\hline Federal & 204.187 & 0 & 11.925 & 12.165 & 180.097 \\
\hline Estadual & 5.279 .951 & 95 & 2.801 .109 & 1.027 .252 & 1.451 .495 \\
\hline Municipal & 3.768 .004 & 1.476 .440 & 2.095 .150 & 70.145 & 126.268 \\
\hline Região Sul & 5.609 .258 & 330.667 & 3.399 .528 & 705.740 & 1.173 .323 \\
\hline Federal & 940.229 & 142 & 71.688 & 63.319 & 805.080 \\
\hline Estadual & 2.798 .789 & 61.923 & 1.739 .338 & 634.694 & 362.835 \\
\hline Municipal & 1.870 .240 & 268.603 & 1.588 .502 & 7.727 & 5.408 \\
\hline Paraná & 2.370 .867 & 113.012 & 1.430 .987 & 322.131 & 504.737 \\
\hline Federal & 221.380 & 142 & 26.178 & 4.601 & 190.459 \\
\hline Estadual & 1.376 .814 & 4.622 & 740.494 & 317.420 & 314.278 \\
\hline Municipal & 772.673 & 108.248 & 664.314 & 111 & 0 \\
\hline Santa Catarina & 1.045 .758 & 105.051 & 606.073 & 134.482 & 200.152 \\
\hline Federal & 201.603 & 0 & 14.930 & 28.779 & 157.895 \\
\hline Estadual & 461.001 & 11.748 & 304.421 & 103.573 & 41.259 \\
\hline Municipal & 383.155 & 93.303 & 286.722 & 2.131 & 999 \\
\hline
\end{tabular}


Tabela 12 - Despesa com educação por dependência admi nistrativa - 1998 (Em R\$1.000 correntes)

(Conclusão)

\begin{tabular}{|c|c|c|c|c|c|}
\hline & Total Geral & Educação Infantil & Ensino Fundamental & Ensino Médio & Educação Superior \\
\hline Rio Grande do Sul & 2.192 .633 & 112.605 & 1.362 .469 & 249.127 & 468.433 \\
\hline Federal & 517.246 & 0 & 30.580 & 29.940 & 456.726 \\
\hline Estadual & 960.974 & 45.552 & 694.423 & 213.701 & 7.298 \\
\hline Municipal & 714.412 & 67.052 & 637.466 & 5.485 & 4.409 \\
\hline Região Centro-Oeste & 3.212 .339 & 158.935 & 2.103 .482 & 399.433 & 550.490 \\
\hline Federal & 723.598 & 0 & 175.528 & 37.377 & 510.693 \\
\hline Estadual & 1.838 .100 & 70.296 & 1.372 .910 & 355.098 & 39.796 \\
\hline Municipal & 650.641 & 88.639 & 555.044 & 6.957 & 0 \\
\hline Mato Grosso do Sul & 497.190 & 20.759 & 329.134 & 56.147 & 91.151 \\
\hline Federal & 91.333 & 0 & 8.156 & 0 & 83.177 \\
\hline Estadual & 249.160 & 1.659 & 185.274 & 54.253 & 7.974 \\
\hline Municipal & 156.697 & 19.099 & 135.704 & 1.894 & 0 \\
\hline Mato Grosso & 590.189 & 24.293 & 389.872 & 72.152 & 103.873 \\
\hline Federal & 110.899 & 0 & 9.550 & 15.170 & 86.178 \\
\hline Estadual & 300.327 & 4.535 & 222.708 & 55.391 & 17.694 \\
\hline Municipal & 178.963 & 19.758 & 157.613 & 1.591 & 0 \\
\hline Goiás & 727.309 & 63.598 & 475.788 & 84.122 & 103.800 \\
\hline Federal & 127.533 & 0 & 15.653 & 22.207 & 89.673 \\
\hline Estadual & 284.795 & 13.816 & 198.409 & 58.443 & 14.127 \\
\hline Municipal & 314.981 & 49.782 & 261.727 & 3.472 & 0 \\
\hline Distrito Federal & 1.397 .652 & 50.286 & 908.688 & 187.012 & 251.665 \\
\hline Federal & 393.833 & 0 & 142.169 & 0 & 251.664 \\
\hline Estadual & 1.003 .819 & 50.286 & 766.519 & 187.012 & 1 \\
\hline Municipal & 0 & 0 & 0 & 0 & 0 \\
\hline Nacional & 821.864 & 0 & 266.707 & 8.006 & 547.150 \\
\hline
\end{tabular}

Fonte: IPEA/DISOC, IBGE/MP, Inep/MEC.

Nota: Gastos por nivel de ensino incluem todas as suas modalidades. 
Tabela 13 - Despesa com educação por dependência admi nistrativa - 1999 (Em R\$1.000 correntes)

(Continua)

\begin{tabular}{|c|c|c|c|c|c|}
\hline & Total Geral & Educação Infantil & Ensino Fundamental & Ensino Médio & Educação Superior \\
\hline Brasil & 41.476 .976 & 3.845 .858 & 24.189.918 & 4.595 .163 & 8.846 .036 \\
\hline Federal & 6.912 .364 & $\ldots$ & 823.649 & 275.624 & 5.813 .091 \\
\hline Estadual & 18.456 .238 & 326.879 & 11.185 .646 & 4.074 .638 & 2.869 .074 \\
\hline Municipal & 16.108 .374 & 3.518 .979 & 12.180 .623 & 244.901 & 163.871 \\
\hline Região Norte & 2.909 .840 & 243.483 & 1.988 .872 & 280.463 & 397.022 \\
\hline Federal & 427.283 & $\ldots$ & 67.829 & 18.978 & 340.476 \\
\hline Estadual & 1.373 .006 & 67.817 & 993.199 & 258.763 & 53.227 \\
\hline Municipal & 1.109 .551 & 175.666 & 927.844 & 2.721 & 3.319 \\
\hline Rondônia & 314.458 & 19.210 & 231.266 & 33.186 & 30.796 \\
\hline Federal & 37.442 & $\ldots$ & 5.455 & 1.211 & 30.775 \\
\hline Estadual & 179.509 & 9.262 & 139.310 & 30.936 & \\
\hline Municipal & 97.507 & 9.948 & 86.501 & 1.038 & 21 \\
\hline Acre & 229.849 & 17.982 & 154.403 & 18.351 & 39.114 \\
\hline Federal & 41.418 & $\ldots$ & 1.925 & 389 & 39.104 \\
\hline Estadual & 114.829 & 10.878 & 86.467 & 17.484 & \\
\hline Municipal & 73.602 & 7.103 & 66.011 & 478 & 10 \\
\hline Amazonas & 634.185 & 49.760 & 430.199 & 64.778 & 89.448 \\
\hline Federal & 98.854 & $\ldots$ & 13.814 & 3.640 & 81.400 \\
\hline Estadual & 302.935 & 2.605 & 231.354 & 60.961 & 8.016 \\
\hline Municipal & 232.395 & 47.155 & 185.030 & 177 & 32 \\
\hline Roraima & 134.696 & 16.084 & 86.122 & 16.971 & 15.519 \\
\hline Federal & 23.404 & $\ldots$ & 6.483 & 1.402 & 15.519 \\
\hline Estadual & 98.649 & 11.322 & 71.798 & 15.529 & \\
\hline Municipal & 12.642 & 4.762 & 7.841 & 39 & 0 \\
\hline Pará & 1.145 .584 & 100.207 & 754.456 & 95.375 & 195.546 \\
\hline Federal & 208.047 & $\ldots$ & 32.448 & 10.340 & 165.259 \\
\hline Estadual & 399.450 & 19.104 & 265.600 & 84.639 & 30.107 \\
\hline Municipal & 538.087 & 81.102 & 456.409 & 395 & 180 \\
\hline
\end{tabular}




\begin{tabular}{|c|c|c|c|c|c|}
\hline \multicolumn{6}{|c|}{ Tabela 13- Despesa com educação por dependência administrativa - 1999 (Em R\$1.000 correntes) } \\
\hline & Total Geral & Educação Infantil & Ensino Fundamental & Ensino Médio & Educação Superior \\
\hline Amapá & 161.938 & 14.132 & 118.725 & 20.663 & 8.418 \\
\hline Federal & 9.848 & & 1.178 & 257 & 8.413 \\
\hline Estadual & 120.900 & 7.289 & 93.257 & 20.353 & \\
\hline Municipal & 31.190 & 6.843 & 24.289 & 53 & 6 \\
\hline Tocantins & 287.121 & 26.109 & 212.086 & 30.744 & 18.181 \\
\hline Federal & 6.262 & $\ldots$ & 4.911 & 1.345 & 6 \\
\hline Estadual & 156.733 & 7.356 & 105.413 & 28.860 & 15.104 \\
\hline Municipal & 124.126 & 18.753 & 101.763 & 540 & 3.070 \\
\hline Região Norte (Geral) & 2.008 & & 1.615 & 394 & \\
\hline Federal & 2.008 & & 1.615 & 394 & \\
\hline \multicolumn{6}{|l|}{ Estadual } \\
\hline \multicolumn{6}{|l|}{ Municipal } \\
\hline Região Nordeste & 9.301 .700 & 743.174 & 6.093 .895 & 795.760 & 1.668 .870 \\
\hline Federal & 1.626 .167 & $\ldots$ & 262.306 & 70.348 & 1.293 .514 \\
\hline Estadual & 3.371 .162 & 88.037 & 2.300 .000 & 626.223 & 356.902 \\
\hline Municipal & 4.304 .371 & 655.138 & 3.531 .589 & 99.189 & 18.454 \\
\hline Maranhão & 983.370 & 92.871 & 702.330 & 80.418 & 107.751 \\
\hline Federal & 105.705 & $\ldots$ & 20.202 & 4.768 & 80.736 \\
\hline Estadual & 345.651 & 15.697 & 246.816 & 58.249 & 24.890 \\
\hline Municipal & 532.014 & 77.174 & 435.312 & 17.401 & 2.126 \\
\hline Piauí & 607.091 & 56.633 & 422.155 & 41.309 & 86.994 \\
\hline Federal & 93.155 & ... & 19.365 & 3.473 & 70.318 \\
\hline Estadual & 275.209 & 20.281 & 202.717 & 36.354 & 15.858 \\
\hline Municipal & 238.727 & 36.353 & 200.074 & 1.482 & 818 \\
\hline Ceará & 1.370 .585 & 129.485 & 894.112 & 134.198 & 212.791 \\
\hline Federal & 205.610 & $\ldots$ & 34.964 & 12.747 & 157.899 \\
\hline Estadual & 483.340 & 2.395 & 313.780 & 114.397 & 52.769 \\
\hline Municipal & 681.636 & 127.090 & 545.368 & 7.053 & 2.124 \\
\hline
\end{tabular}


Tabela 13 - Despesa com educação por dependência administrativa - 1999 (Em R\$ 1.000 correntes)

(Continuação)

\begin{tabular}{|c|c|c|c|c|c|}
\hline & Total Geral & Educação Infantil & Ensino Fundamental & Ensino Médio & Educação Superior \\
\hline Rio Grande do Norte & 795.865 & 51.307 & 491.253 & 81.877 & 171.428 \\
\hline Federal & 190.165 & $\ldots$ & 24.791 & 6.165 & 159.210 \\
\hline Estadual & 375.777 & 6.746 & 286.344 & 71.209 & 11.478 \\
\hline Municipal & 229.922 & 44.561 & 180.118 & 4.503 & 741 \\
\hline Paraíba & 765.409 & 56.766 & 401.569 & 48.504 & 258.570 \\
\hline Federal & 266.559 & $\ldots$ & 29.009 & 6.951 & 230.600 \\
\hline Estadual & 226.530 & 11.939 & 151.306 & 36.253 & 27.032 \\
\hline Municipal & 272.320 & 44.827 & 221.255 & 5.300 & 938 \\
\hline Pernambuco & 1.324 .370 & 92.427 & 826.572 & 130.739 & 274.633 \\
\hline Federal & 260.231 & $\ldots$ & 42.337 & 13.885 & 204.009 \\
\hline Estadual & 463.416 & 2.423 & 299.944 & 98.368 & 62.681 \\
\hline Municipal & 600.723 & 90.003 & 484.290 & 18.486 & 7.943 \\
\hline Alagoas & 536.827 & 29.935 & 319.393 & 23.837 & 163.662 \\
\hline Federal & 188.134 & $\ldots$ & 29.089 & 5.490 & 153.555 \\
\hline Estadual & 100.674 & 1.353 & 75.712 & 14.288 & 9.321 \\
\hline Municipal & 248.018 & 28.582 & 214.591 & 4.060 & 785 \\
\hline Sergipe & 432.287 & 55.658 & 288.668 & 38.665 & 49.296 \\
\hline Federal & 67.986 & $\ldots$ & 15.782 & 3.357 & 48.848 \\
\hline Estadual & 210.533 & 21.024 & 156.271 & 33.237 & \\
\hline Municipal & 153.768 & 34.633 & 116.615 & 2.072 & 448 \\
\hline Bahia & 2.485 .896 & 178.093 & 1.747 .843 & 216.214 & 343.746 \\
\hline Federal & 248.623 & $\ldots$ & 46.768 & 13.514 & 188.341 \\
\hline Estadual & 890.031 & 6.179 & 567.110 & 163.868 & 152.873 \\
\hline Municipal & 1.347 .243 & 171.914 & 1.133 .965 & 38.832 & 2.531 \\
\hline Região Sudeste & 19.039 .072 & 2.161.977 & 10.307 .125 & 2.328 .160 & 4.241 .810 \\
\hline Federal & 2.360 .718 & & 182.369 & 80.982 & 2.097 .367 \\
\hline Estadual & 9.198 .073 & 42.897 & 5.016 .312 & 2.129 .111 & 2.009 .753 \\
\hline Municipal & 7.480 .281 & 2.119 .081 & 5.108 .444 & 118.066 & 134.691 \\
\hline
\end{tabular}




\begin{tabular}{|c|c|c|c|c|c|}
\hline \multicolumn{6}{|c|}{ Tabela 13 - Despesa com educação por dependência admi nistrativa - 1999 (Em R\$1.000 correntes) } \\
\hline & Total Geral & Educação Infantil & Ensino Fundamental & Ensino Médio & Educação Superior \\
\hline Minas Gerais & 4.162 .921 & 267.168 & 2.773 .009 & 482.156 & 640.588 \\
\hline Federal & 677.393 & 0 & 16.779 & 49.370 & 611.244 \\
\hline Estadual & 1.981.194 & 10.055 & 1.549 .605 & 392.191 & 29.344 \\
\hline Municipal & 1.504 .334 & 257.113 & 1.206 .625 & 40.596 & 0 \\
\hline Espírito Santo & 804.544 & 68.408 & 531.158 & 121.751 & 83.227 \\
\hline Federal & 108.479 & 0 & 8.731 & 23.367 & 76.382 \\
\hline Estadual & 410.076 & 7.764 & 307.015 & 93.738 & 1.558 \\
\hline Municipal & 285.990 & 60.644 & 215.412 & 4.646 & 5.288 \\
\hline Rio de Janeiro & 3.689 .417 & 253.387 & 1.783 .523 & 453.332 & 1.199 .175 \\
\hline Federal & 940.427 & 0 & 80.003 & 122.487 & 737.937 \\
\hline Estadual & 1.464 .200 & 34.590 & 659.922 & 308.450 & 461.238 \\
\hline Municipal & 1.284 .790 & 218.798 & 1.043 .598 & 22.395 & 0 \\
\hline São Paulo & 9.252 .142 & 1.476 .535 & 4.908 .185 & 1.109 .562 & 1.757 .860 \\
\hline Federal & 204.187 & 0 & 11.925 & 12.165 & 180.097 \\
\hline Estadual & 5.279 .951 & 95 & 2.801 .109 & 1.027 .252 & 1.451 .495 \\
\hline Municipal & 3.768 .004 & 1.476 .440 & 2.095 .150 & 70.145 & 126.268 \\
\hline Região Sul & 5.609 .258 & 330.667 & 3.399 .528 & 705.740 & 1.173 .323 \\
\hline Federal & 940.229 & 142 & 71.688 & 63.319 & 805.080 \\
\hline Estadual & 2.798 .789 & 61.923 & 1.739 .338 & 634.694 & 362.835 \\
\hline Municipal & 1.870 .240 & 268.603 & 1.588 .502 & 7.727 & 5.408 \\
\hline Paraná & 2.370 .867 & 113.012 & 1.430 .987 & 322.131 & 504.737 \\
\hline Federal & 221.380 & 142 & 26.178 & 4.601 & 190.459 \\
\hline Estadual & 1.376 .814 & 4.622 & 740.494 & 317.420 & 314.278 \\
\hline Municipal & 772.673 & 108.248 & 664.314 & 111 & 0 \\
\hline Santa Catarina & 1.045 .758 & 105.051 & 606.073 & 134.482 & 200.152 \\
\hline Federal & 201.603 & 0 & 14.930 & 28.779 & 157.895 \\
\hline Estadual & 461.001 & 11.748 & 304.421 & 103.573 & 41.259 \\
\hline Municipal & 383.155 & 93.303 & 286.722 & 2.131 & 999 \\
\hline
\end{tabular}


Tabela 13 - Despesa com educação por dependência admi nistrativa - 1999 (Em R\$1.000 correntes)

(Conclusão)

\begin{tabular}{|c|c|c|c|c|c|}
\hline & Total Geral & Educação Infantil & Ensino Fundamental & Ensino Médio & Educação Superior \\
\hline Rio Grande do Sul & 2.601 .455 & 171.132 & 1.601 .960 & 251.952 & 576.412 \\
\hline Federal & 614.218 & & 38.055 & 12.643 & 563.520 \\
\hline Estadual & 958.022 & 45.686 & 679.767 & 225.833 & 6.735 \\
\hline Municipal & 1.029 .216 & 125.445 & 884.138 & 13.476 & 6.157 \\
\hline Região Centro-Oeste & 3.412 .468 & 204.476 & 2.128 .103 & 432.641 & 647.247 \\
\hline Federal & 790.094 & & 138.223 & 41.848 & 610.023 \\
\hline Estadual & 1.745 .149 & 62.971 & 1.261 .444 & 383.510 & 37.224 \\
\hline Municipal & 877.225 & 141.506 & 728.436 & 7.283 & \\
\hline Mato Grosso do Sul & 614.422 & 38.098 & 384.877 & 66.556 & 124.891 \\
\hline Federal & 122.675 & & 4.741 & 1.479 & 116.454 \\
\hline Estadual & 278.219 & 2.812 & 203.482 & 63.487 & 8.437 \\
\hline Municipal & 213.529 & 35.286 & 176.654 & 1.590 & \\
\hline Mato Grosso & 771.464 & 35.840 & 525.798 & 92.062 & 117.764 \\
\hline Federal & 127.696 & & 20.236 & 5.840 & 101.620 \\
\hline Estadual & 395.759 & 2.786 & 292.432 & 84.396 & 16.145 \\
\hline Municipal & 248.010 & 33.054 & 213.130 & 1.826 & \\
\hline Goiás & 922.671 & 91.105 & 615.622 & 95.258 & 120.685 \\
\hline Federal & 143.949 & & 26.998 & 8.908 & 108.043 \\
\hline Estadual & 363.036 & 17.939 & 249.972 & 82.482 & 12.642 \\
\hline Municipal & 415.686 & 73.166 & 338.652 & 3.868 & \\
\hline Distrito Federal & 1.103 .911 & 39.433 & 601.806 & 178.765 & 283.907 \\
\hline Federal & 395.775 & & 86.248 & 25.620 & 283.907 \\
\hline Estadual & 708.136 & 39.433 & 515.558 & 153.145 & \\
\hline Nacional & 625.080 & & 95.486 & 34.226 & 495.368 \\
\hline
\end{tabular}

Fonte: IPEA/DISOC, IBGE/MP, Inep/MEC.

Nota: Gastos por nivel de ensino incluem todas as suas modalidades. 


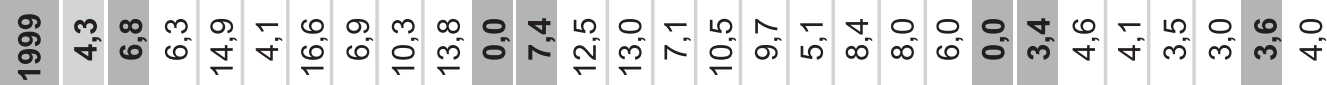

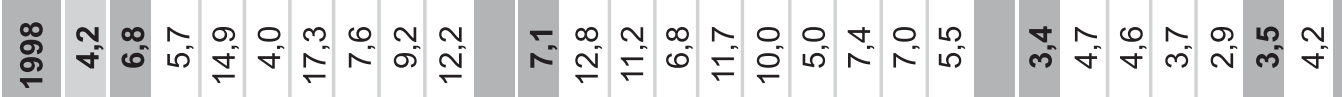

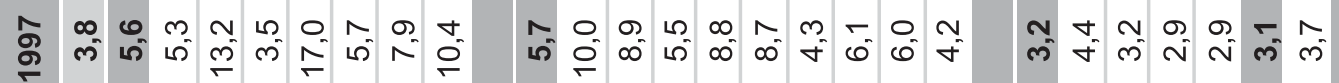

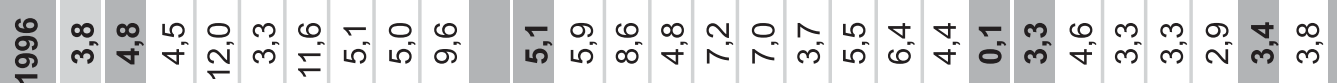

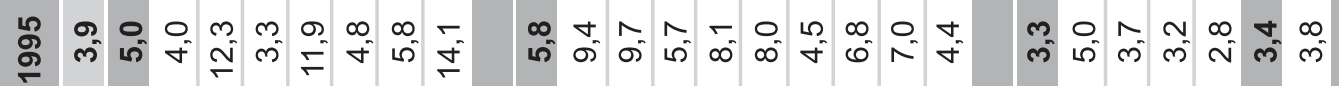

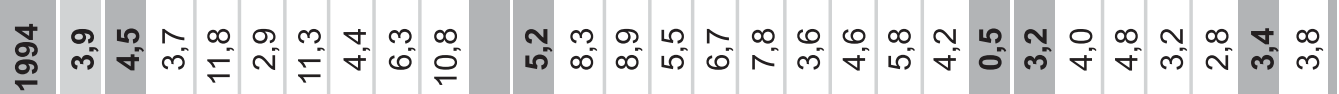

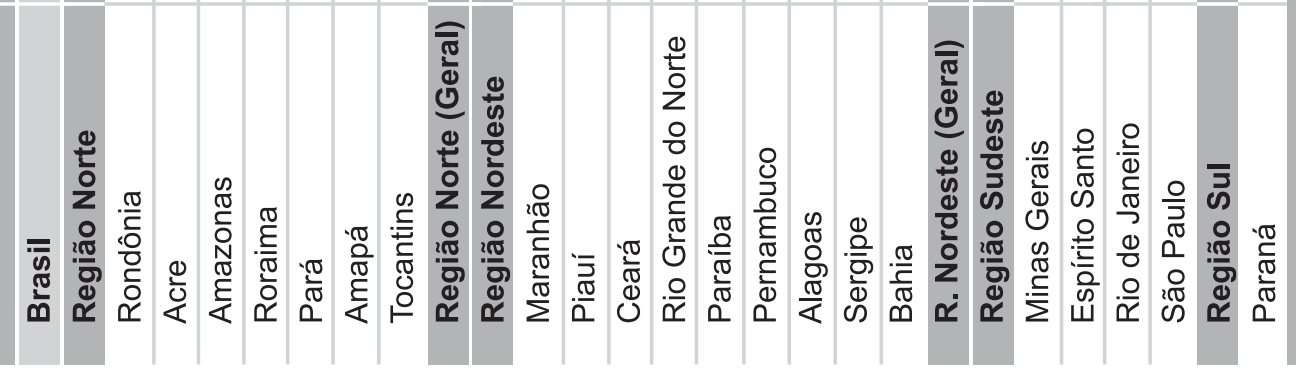




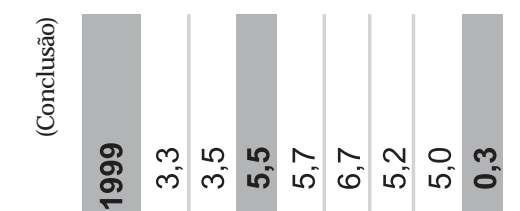

号 N

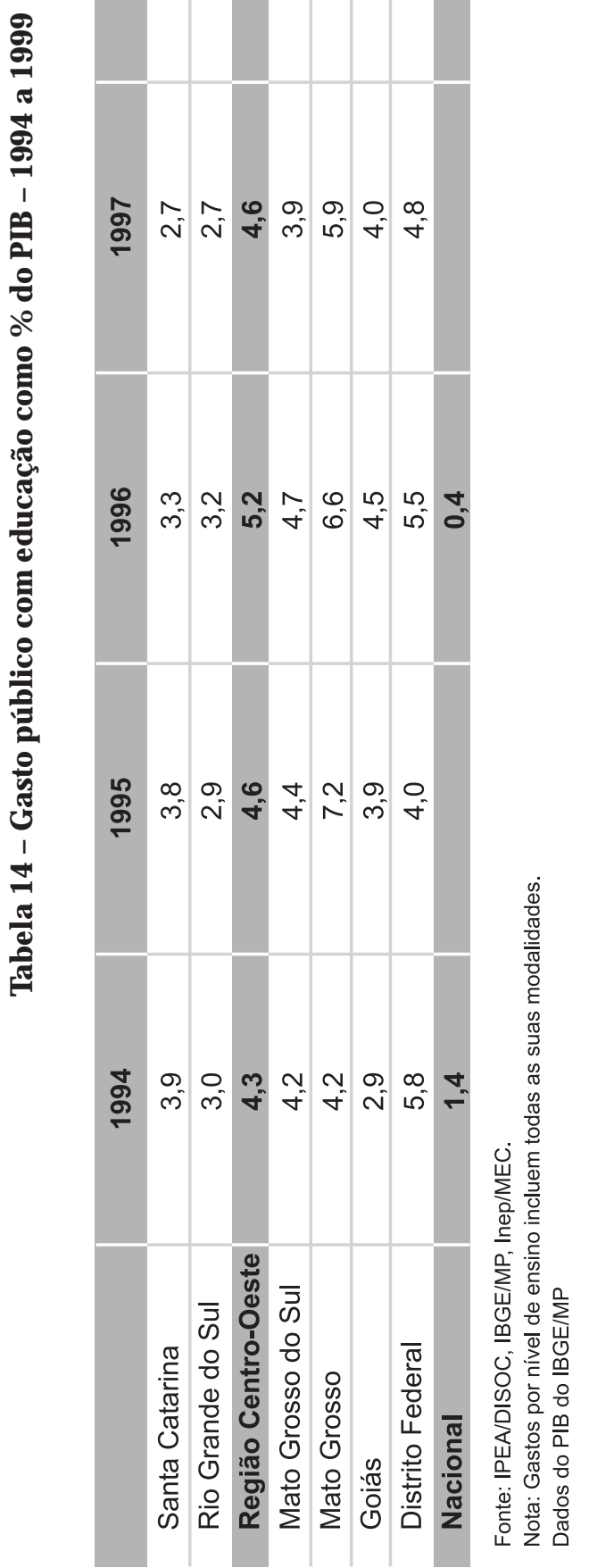

